\title{
UNITED NATIONS ECONOMIC COMMISSION FOR EUROPE
}

Financing for Development

UN/ECE Regional Conference

In co-operation with the EBRD and UNCTAD

6-7 December 2000

\section{" CAPITAL FLOWS TO DEVELOPING COUNTRIES AND THE REFORM OF THE INTERNATIONAL FINANCIAL SYSTEM "}

Background Paper for Special Session IV on Global Financial Issues* prepared by

Yilmaz Akyüz and Andrew Cornford 
UNITED NATIONS CONFERENCE ON TRADE AND DEVELOPMENT

\title{
CAPITAL FLOWS TO DEVELOPING COUNTRIES AND THE REFORM OF THE INTERNATIONAL FINANCIAL SYSTEM
}

\author{
Yilmaz Akyïz \\ and Andrew Cornford
}

No. 143

November 1999

\section{DISCUSSION PAPERS}




\title{
CAPITAL FLOWS TO DEVELOPING COUNTRIES AND THE REFORM OF THE INTERNATIONAL FINANCIAL SYSTEM
}

\author{
Yilmaz Akyüz \\ and Andrew Cornford
}

No. 143

November 1999

\footnotetext{
This paper was prepared for the WIDER Project, New Roles and Functions for the UN and the Bretton Woods Institutions. A shorter version is to be published in the volume also containing other papers prepared for the project and edited by Professor Deepak Nayyar. The authors are grateful to Detlef Kotte and Cora Punsalan for contributions to the statistical analysis. They have also benefited from discussion with Jan Kregel. Any errors and omissions are, of course, the responsibility of the authors.
} 
The opinions expressed in this paper are those of the authors and do not necessarily reflect the views of UNCTAD. The designations and terminology employed are also those of the authors.

UNCTAD Discussion Papers are read anonymously by at least one referee, whose comments are taken into account before publication.

Comments on this paper are invited and should be addressed to the authors, c/o Editorial Assistant*, Macroeconomic and Development Policies, GDS, United Nations Conference on Trade and Development (UNCTAD), Palais des Nations, CH-1211 Geneva 10, Switzerland. Copies of Discussion Papers and Reprint Series may also be obtained from this address. Extracts of new Discussion Papers are available on the web site at: http://www.unctad.org/en/pub/pubframe.htm

* Tel. 022-907.5733; Fax 907.0274; E.mail: nicole.winch@ unctad.org 


\section{CONTENTS}

I. INTERNATIONAL INSTITUTIONS AND THE GOVERNANCE OF CAPITAL FLOWS

II. TRENDS IN EXTERNAL FINANCING FOR DEVELOPING COUNTRIES 8

$\begin{array}{ll}\text { III. FINANCIAL INSTABILITY AND CRISES } & 15\end{array}$

IV. POLICY RESPONSES 18

$\begin{array}{ll}\text { A. Monetary policies } & 19\end{array}$

B. Foreign-exchange reserves and lines of credit 19

C. Transparency, disclosure and early warning 20

D. Financial regulation and supervision 26

1. The reform of the Basle Capital Accord 27

2. A World Financial Authority 28

3. The limits of prudential regulation $\quad 29$

E. Policy surveillance 30

F. An international lender of last resort 33

G. Orderly debt workouts 36

V. CONCLUSIONS $\quad 41$

$\begin{array}{ll}\text { REFERENCES } & 43\end{array}$ 


\title{
CAPITAL FLOWS TO DEVELOPING COUNTRIES AND THE REFORM OF THE INTERNATIONAL FINANCIAL SYSTEM
}

\author{
Yilmaz Akyuz and Andrew Cornford \\ United Nations Conference on Trade and Development, Geneva
}

\begin{abstract}
Recent financial crises, whose effects have been particularly severe in developing countries, have led to a wide-ranging debate on international financial reform. This debate has had to confront the implications of the huge growth of international capital movements, one of whose consequences has been the increased privatization of external financing for developing countries. The paper begins with surveys of major features of the post-war evolution of the system of governance of the international financial system and of the principal trends in capital flows to developing countries during the past three decades. These set the stage for a selective review of appropriate policy responses to international financial instability, with the main focus on proposals for remedying structural and institutional weaknesses in the global financial architecture through such means as greater transparency and improved disclosure, strengthened financial regulation and supervision, more comprehensive and even-handed multilateral policy surveillance, and bailing in the private sector by arrangements for orderly debt workouts. In view of the continuing absence of effective measures at the global level for dealing with financial instability, the paper puts special emphasis on the maintenance by developing countries of national autonomy regarding policy towards capital movements.
\end{abstract}

\section{INTERNATIONAL INSTITUTIONS AND THE GOVERNANCE OF CAPITAL FLOWS}

The ideas underlying approaches to improving the governance of the international financial system since 1945 have understandably been heavily influenced by the experience of the recent past. Thus the arrangements which emerged from planning during World War II and the negotiations following it reflected the searing impact on thinkers and policy makers of the 1930s - the devastating declines in employment and incomes of the Great Depression and the associated contraction in international trade, the recourse to competitive devaluations and multiple currency practices, and the proliferation of bilateral trade arrangements and exchange controls. Similarly, much of policy makers' energy immediately after the war was focused on the international financing and payments requirements of the economic reconstruction of Western Europe. The very concepts used in discussion of policy issues involving the international financial system tended to be based, explicitly or implicitly, on assumptions about its functioning which reflected to a great extent the commonest categories of cross-border financial transaction and prevalent rules and norms. The concepts of international liquidity and of the various possible instruments for its provision in this discussion, for example, were closely connected to their use for international trade in goods and services and for the still relatively restricted categories of capital 
transaction which could be undertaken within the rules of the national regimes of most developed countries during this period.

From the 1950s onwards there was an expansion of the international capital markets, driven partly by the flows of international investment linked to post-war economic recovery but also stimulated by the development of offshore currency markets where financial transactions were subject to much lighter control. ${ }^{1}$ Countries were periodically (and from the second half of the 1960s increasingly frequently) subjected to pressures due to surges of short-term capital flows between major currencies, ${ }^{2}$ surges which eventually overwhelmed the Bretton Woods system of exchange rates. Henceforth, while problems associated with the financing and payments arrangements of trade and other current-account transactions have remained an important concern in consideration of the functioning of the international financial system (a statement which for obvious reasons applies a fortiori to matters associated with developing countries participation in this system), increasing attention has been devoted to ways of handling, controlling and responding to capital movements as these have continued to grow in size, unshackled as they increasingly have been owing to the progressive liberalization of capital-account transactions in the major industrial countries and to some extent elsewhere.

As is documented in the following section, this trend in the functioning of the international financial system towards increased importance for private actors was eventually paralleled by an analogous one in the character of developing countries' external financing, with a rapid increase in the importance of private flows during the 1970s and the 1990s (though one which experienced a set back owing to the debt crisis in the 1980s). The progressive integration of developing (and more recently transition) economies into the network of international financial markets has had the consequence that the benefits and costs of this increased "privatization" of these economies' external financing has become a much more important topic in debate concerning the international financial system. Moreover, developments in the 1990s, especially the destabilizing spillovers on financial markets and firms of industrial countries from the financial crises in Russia and East Asia and Russia, have provided additional impetus to this tendency, so that the omission of the problems posed by capital movements for countries with "emerging financial markets" is no longer conceivable in serious consideration of systemic reform of international financial governance.

A comprehensive description of the main instruments and arrangements for this governance (and thus also of the governance of international capital flows) is of course impossible in a paper of this

Offshore currency markets which, like offshore banking, lack a generally accepted precise definition, refer to financial activities in currencies other than that of the country where they are located or between non-residents of this country (or to activities characterized by both features). Typically, they are free of many of the monetary controls and regulations which apply to onshore markets, and benefit from tax advantages.

"By the time that the adjustable peg was abandoned, capital mobility had developed to the point where the Bundesbank could take in well over $\$ 1$ billion in an hour when the market had come to expect that another parity change was impending" (Williamson, 1997: 50). 
length, but a brief sketch of major features should facilitate understanding of the arguments which follow.

The planning for the post-war world during World War II envisaged a set of organizations which would deal with currency stability and international payments, economic reconstruction and the advancement of less developed economies, and international trade and investment. The negotiations associated with this process eventually gave rise to the IMF, the World Bank, and the GATT. ${ }^{3}$ But the triad which emerged from Bretton Woods and its aftermath are merely the monoliths of a set of about 300 international organizations dealing with economic matters with memberships varying from the near universal to the purely regional, some of which antedate World War II. ${ }^{4}$ Of the organizations other than those which emerged from Bretton Woods the most important in the context of the governance of international capital flows are the OECD, the EEC/EU, and the BIS.

Responsibility for international capital movements is not neatly assigned under this institutional structure. Indeed, the original structure did not include a global regime for capital movements, and no such regime has yet emerged. Instead at the global level there is a patchwork of rules and agreements bearing directly or indirectly on several aspects of international investment and other financial flows but one which still accommodates a considerable measure of national policy autonomy for the majority of countries. More comprehensive regimes, designed to liberalize international financial flows, have been agreed in arrangements involving limited groups of countries such as the OECD, the EEC/EU, and the BIS.

The only global regime applying to cross-border monetary transactions is that of the IMF but the most important obligations in its Articles of Agreement relate to current and not capital transactions (being set out in Articles VIII and XIV). Concerning capital movements Article IV contains the statement that one of the essential purposes of the international monetary system is to provide a framework facilitating the exchange of capital among countries, a statement which is included among general obligations regarding exchange arrangements. The more specific references to capital transfers in Article VI permit recourse to capital controls so long as they do not restrict payments for current transactions, and actually give the Fund the authority to request a member country to impose contracts to prevent the rise of funds from its general Resources Account to finance a large or sustained capital outflow. The World Bank has no direct responsibility for governance of the international financial system. However, it has participated as a source of financing in a number of the international bail-outs put together in response to recent financial crises, and has provided financial and technical assistance (often as a major ingredient of programmes linked to structural adjustment lending) to several countries

In the planning for the post-war world, the organizations responsible for global economic governance were linked to the United Nations, which would be responsible for the maintenance of peace. The IMF and the World Bank are Specialized Agencies of the United Nations under Article 57 of its Charter. The United Nations has concluded agreements with them under Article 63, recognizing them as independent international organizations. 
as part of their efforts to upgrade and reform their financial sectors and their regimes of regulation and supervision (now considered an important part of policies for preventing financial crises, as explained below). Until 1994 GATT likewise was assigned only very limited responsibility regarding the functioning of the international financial system: Articles XII-XV and section B of Article XVIII of the Agreement permit the use of quantitative restrictions on imports by countries facing balance-of-payments problems but in this context the judgement of the IMF is sought as to the validity of the reasons advanced to support the imposition and maintenance of these restrictions. The WTO agreement, while not giving the new institution a major role in global financial governance, has nevertheless extended its remit regarding international investment, in particular through the inclusion of the commercial presence of (and thus the FDI of) services suppliers in the GATS. Since the sectors covered by the GATS include financial services, both the pace and the nature of the expansion of the global network of financial markets will henceforth be significantly affected by commitments as to market access and national treatment made in WTO negotiations.

Of the organizations or arrangements with more limited memberships both the OECD and the EEC/EU have established regimes for capital flows. ${ }^{5}$ The OECD Code of Liberalization of Capital Movements dates from 1961 and reflects the generally favourable view of its member states concerning the free movement of capital. The Code discriminates between two sets (or Lists) of capital movement, and member countries authorize transactions in the two Lists subject only to reservations listed in an Annex to the Code, and to derogations granted in certain circumstances such as the onset of serious balance-of-payments problems. One of the two Lists covers transactions generally regarded as more sensitive owing, for example, to their short-term and potentially more speculative character, and is consequently subject to greater flexibility as to the right to enter reservations. ${ }^{6}$ In the EEC/EU a 1988 directive abolished restrictions on capital movements between residents of EEC/EU countries subject only to provisos concerning the right to control short-term movements during periods of financial strain and to take the measures necessary for the proper functioning of systems of taxation, prudential supervision, etc. ${ }^{7}$ The directive also stated that EEC/EU countries should endeavour to attain the same degree of liberalization of capital movements vis-à-vis third countries as with other member countries. Under the directive governments retained the right to take protective measures with regard to certain capital transactions in response to disruptive short-term capital movements but, since the introduction of the

For more detail see Akyüz and Cornford (1995).

6 Derogation from full compliance with the Code's obligations is also possible if a country's "economic and financial situation justifies such a course". Once surrendered, however, this dispensation is no longer available. The derogation, which inter alia is intended to cover developing countries, has been used in various cases, for example by Greece, Iceland, Spain, Turkey and Portugal (with respect to its overseas territories). See OECD (1990: 21).

Prior to the 1988 directive, the EEC/EU's regime for capital movements had provided governments some leeway for restricting different categories of transaction, with liberalization obligations which were less stringent for short-term and potentially speculative transactions. 
single currency, for the countries adopting it such measures may only be taken towards capital movements to or from third countries. The EEC/EU also made available to member countries various types of external payments support both for the purpose enabling participants in its exchange-rate mechanism (ERM) to keep their currencies within prescribed fluctuation limits and for other circumstances threatening orderly conditions in the market for a member country's currency. Since the introduction of the single currency the application of these arrangements has been substantially restricted but experience of their use remains of interest to other regional groupings contemplating the establishment of mechanisms for mutual external financial support. ${ }^{8}$

The BIS was established in 1930 "to promote the cooperation of central banks and to provide additional facilities for international financial operations; and to act as trustee or agent in regard to international financial settlements entrusted to it". ${ }^{9}$ Since the 1970s the BIS has become the principal forum and provided the secretariat support for a number of bodies established to reduce or manage the risks in cross-border banking transactions. The best known of these bodies is the Basle Committee on Banking Supervision established to promote banking stability through the promotion of strengthened regulation and improved cooperation between national supervisors. Others include the Committee on the Global Financial System (until February 1999 known as the Euro-Currency Standing Committee) established to monitor international banking developments and to disseminate data on the subject from national creditor sources (a source of warnings as early as 1996 concerning the dangers of the increased short-term borrowing of certain East Asian countries), and the Committee on Payment and Settlement Systems, the principal focus of whose work is the timely settlement of large-scale financial transfers but which has also more recently begun to devote attention to the implications of electronic money. While the Basle bodies are not responsible for setting rules for international capital movements as such, their work is designed to strengthen the defences of financial firms both individually and in the aggregate against destabilization due to cross-border transactions and risk exposures. In its work on financial firms' involvement in securities transactions the Basle Committee on Banking Supervision has often collaborated with the International Organization of Securities Commissions (IOSCO), which has a membership consisting of securities regulators and exchanges and which has gradually extended its remit from one concentrating primarily on information sharing to the setting and promulgation of standards

For a useful but not fully up-to-date survey of mechanisms for external payments support in the EEC, see Edwards (1985: 326-346). As part of the establishment of the Economic and Monetary Union, the European Monetary Cooperation Fund, the vehicle which administered short-term facilities under the heading of mutual external financial support, was dissolved and its functions taken over by the European Monetary Institute (EMI).

See Article 3 of the statutes of the Bank for International Settlements. For a useful summary of the history, structure, functions and legal status of the BIS, see Edwards (1985: 52-63). Until recently the principal shareholders of the BIS were 28 predominantly West European central banks, those of Belgium, France, Germany, Italy and United Kingdom holding over 50 per cent of the votes. The United States Federal Reserve participates in meetings and committees linked to the BIS without being a shareholder. As a response to the increasingly global character of the international financial cooperation in which the BIS and bodies linked to it play an increasingly important role, in September 1996 the BIS invited nine additional central banks to become shareholders: those of China, Brazil, Hong Kong (China), India, Republic of Korea, Mexico, Russian Federation, Saudi Arabia and Singapore. 
for the functioning of exchanges and securities firms and for surveillance of cross-border securities transactions. One other recently established body, the Financial Stability Forum (which is describes in more detail below), has a secretariat located in Basle, and is chaired by the General Manager of the BIS.

Other regional organizations have remits bearing in various ways on international capital movements: various groups of banking supervisors other than the Basle Committee (both regional and comprising offshore financial centres) deal with regulatory issues affecting their members, typically maintaining close contact in this context with the Basle Committee; and in Asia there are institutions and arrangements which may eventually come to play roles similar to those of the EEC/EU in the areas of mutual consultation and external payments support, namely the Executive Meeting of East Asia and Pacific Central Banks (EMEAP) (which, inter alia, monitors foreign exchange markets in the region), swap mechanisms among ASEAN countries, and a web of bilateral repurchase agreements between monetary authorities of the region under which an authority may exchange its United States Treasury securities for dollars needed to support its currency.

A great many features of the current international financial system have a significant (even if often only indirect) bearing on international capital flows. Thus proposed reforms of this system can generally be expected to affect the scale and character of these flows. Any discussion such as that which follows is necessarily selective, and many readers may feel that important ideas have been only touched upon or completely omitted. The survey here concerns policies which have been at the centre of discussion (particularly concerning economies with emerging financial markets) since the East Asian crisis of 1997 but even so is not comprehensive. Some readers may feel disappointed at the absence of discussion of exchange-rate regimes, of proposals for tighter control of international lending and portfolio investment at the source, or of the tax on foreign-exchange transactions originally proposed by James Tobin as an instrument for limiting the volatility of currency markets and capital movements. Concerning the latter the authors had expressed their scepticism on a number of occasions before the outbreak of the East Asian crisis, which has not changed their views. ${ }^{10}$ Regarding tighter controls on external financial flows at their source the more ambitious proposals would appear typically to have features which are an obstacle to their adoption, while the ameliorative ones which might face less resistance are unlikely to so reduce financial instability as to eliminate the need for other major changes on the agenda of reform. ${ }^{11}$ As to exchange-rate regimes, for reasons explained at greater length elsewhere, the authors are not convinced, unlike many other commentators, that this crisis furnished decisive arguments against

\footnotetext{
10 See, for example, the survey of global policy actions in UNCTAD (1996b: Annex, sect. F) and Cornford (1996) (which is a review article of the book of papers generally more sympathetic to Tobin's proposal (Ul Haque et al., 1996).

11 The more ambitious proposals include that for an International Credit Insurance Corporation, which would guarantee international loans for a modest fee, while setting a ceiling on the amount of borrowing by particular countries which it was willing to insure. Of the ameliorative proposals, that for raising the costs of international interbank lending is actually discussed below in section IV.D.1, and others are designed to achieve objectives such as the slowing of disinvestment in developing-country stocks by mutual funds. For a longer discussion see UNCTAD (1998a: chap. IV, sect. C.4).
} 
managed flexibility for currencies (so long as it is accompanied by effective management of external liabilities). The way in which currency regimes were managed in certain East Asian countries (in effect through pegging to the United States dollar) doubtless played a role in the unfolding of the crisis. But in conditions of high capital mobility no exchange-rate regime can guarantee stable and competitive rates. Freely floating exchange rates and rigidly fixed ones (currency boards) each impose costs of their own, the one introducing considerable uncertainly into a country's relations with its trading and investment partners and the other sharply (and almost certainly for many countries unacceptably) reducing national policy autonomy. ${ }^{12}$

As is implicit in the remarks opening this section, ideas concerning international financial reform have a way of always being provisional owing to their susceptibility to being at least partly overtaken by developments on the ground. Cross-border financial transactions - current as well as capital - have been greatly transformed by financial innovation in recent years, and this process can be expected to continue. Derivatives are often cited in this context owing to the way in which they can be used to get around the spirit, if not the letter, of regulation of capital-account transactions. ${ }^{13}$ In the not too distant future it is possible that new techniques of payment and settlement of cross-border transactions made possible by computer technology will be a source of new challenges to techniques of monetary policy and to tax systems. These challenges may involve the design of rules for the new arrangements for such payment and settlement, techniques of valuation for instruments such as financial assets other than money used for this purpose, and the intervention in the markets for financial and possibly other assets required to avoid levels of price instability capable of disrupting these arrangements. ${ }^{14}$ The challenges will inevitably affect both regimes for international capital movements and the agenda for international financial reform.

\footnotetext{
12 For a more extended discussion see UNCTAD (1998a: Part One, chap. IV, sect. C.6) and UNCTAD (1999b: chap. VI, sect. B.1).

13 One simple example, pointed out by Robert Merton, is the way in which cross-border swaps of income flows make possible the taking of positions in foreign assets (in Merton's example stocks) by a country's investors without their purchasing the underlying assets involved, which may be prohibited by the country's regime for capital-account transactions. See Mason, Merton, Perold, and Tufano (1995: 4-7).

14 New situations in banking and finance often lead to renewed attention to, or rediscovery of, old ideas, and in the context of possible future techniques for stabilizing the value of assets used for payment and settlement one can envisage renewed interest in linking international monetary policy to stabilization of goods or commodity prices, as proposed to the first UNCTAD conference in 1964 by Kaldor et al. (1964), or much earlier on by Benjamin Graham in Graham (1944).
} 


\section{TRENDS IN EXTERNAL FINANCING FOR DEVELOPING COUNTRIES}

As shown in table 1 and charts 1-2, the size, composition and distribution of external capital inflows ${ }^{15}$ to developing countries have all undergone fundamental shifts during the past three decades. In the period until the early 1970s the most important source of external financing for developing countries was official loans and aid (though during the period from the 1950s onwards FDI frequently accounted for 20-30 per cent of their external financing and there was also an expansion in the share accounted for by export credits). This was based on the recognition that the ability of developing countries to fill their resource gaps through commercial borrowing on market terms was severely limited. Official financing continued to expand rapidly in the 1970s but there was also a rapid expansion of private financial flows, primarily in the form of credits by banks in industrial countries, which served to recycle the surpluses of major oil exporters that emerged after the sharp increases in oil prices during 1973-1974. This expansion came to an end in 1982 with a rapid withdrawal of bank lending, resulting in a generalized debt crisis in the third world and a lost decade for growth and development. During the rest of the 1980s capital inflows to developing countries remained virtually stagnant: while private financing fell sharply, official development assistance increased only moderately compared to the 1970s. Until 1997 the decade of the 1990s witnessed a strong expansion in private capital inflows to developing countries. The increase was sufficiently rapid to more than offset the downward trend in official flows, and was greatly influenced by rapid liberalization of markets and privatization of economic activity in most developing countries. An important proportion of private capital has taken the form of non-debt creating flows, notably but not exclusively FDI. ${ }^{16}$

Net capital inflows to developing countries have risen by more than twenty-fold in nominal terms since 1970. In real terms the increase in total net inflows is much less impressive. Measured in relation to the import price index of developing countries (i.e. in terms of its purchasing power over foreign goods), for example, the increase in net capital inflows during the same period is about five-fold. More importantly, measured in terms of the share of output of the recipient countries, the recent surge in capital flows represents only a recovery from the stagnant levels of the 1980s rather than an increase over the levels attained during the years preceding the debt crisis. Excluding China, on average the total inflow of capital to developing countries as a proportion of their combined GNP was indeed lower during 1990-1998 than during 1975-1982. Similar trends are also observable for net transfers, namely net capital inflows less net factor payments abroad including interest payments on external debt and profit remittances which is a broad measure of foreign resources available to finance

\footnotetext{
15 For the terminology regarding capital flows in this paper see the notes to table 1.

16 In this context it should be recalled that FDI includes not only non-debt-creating flows but also intercompany debt transactions.
} 
Table 1

Aggregate net capital inflow to developing countries, By type of flow, and net transfer, 19751998

\begin{tabular}{lccc}
\hline & $1975-1982$ & $1983-1989$ & $1990-1998$ \\
\hline & & & \\
& & & \\
Total net inflow & & & 5.00 \\
Including China & 4.91 & 2.87 & 4.22 \\
Excluding China & 5.45 & 2.97 & 1.03 \\
Official inflows & & & 0.56 \\
ODA grants & 1.58 & 1.57 & 0.47 \\
Other official & 0.53 & 0.62 & 3.97 \\
Private inflows & 1.05 & 0.96 & 2.21 \\
Non-debt-creating inflows & & & 1.67 \\
$\quad$ FDI & 3.33 & 1.29 & 0.54 \\
Portfolio equity & 0.42 & 0.55 & 0.52 \\
Bonds & 0.42 & 0.53 & 1.17 \\
Bank credit & 0.00 & 0.02 & 0.72 \\
Short-term & 0.11 & 0.05 & 0.44 \\
Long-term & 2.46 & 0.44 & 1.79 \\
Memo item: & 1.10 & 0.10 & 0.56 \\
Portfolio inflows & 1.36 & 0.34 & 2.65 \\
\hline Net capital transfers & & & 1.06 \\
\hline
\end{tabular}

Sources: UNCTAD secretariat estimates, based on World Bank, Global Development Finance, 1999 (CD-Rom, Washington DC, 1999).

\section{Definition of Different Types of Capital Flows}

There is ambiguity in terminology for the different kinds of international capital flows. The same terms used by different institutions or writers often cover different categories of capital transactions, while the same categories are sometimes referred to in different terms. The definitions used throughout this paper are as follows:

Capital inflow: This term refers to the acquisition of domestic assets by non-residents (plus grants). Sales of domestic assets are defined as a negative capital inflow. Thus the term net capital inflow denotes acquisition minus sales of domestic assets by non-residents. The types of asset included in these flows vary according to the institution publishing the data. The term net resource flows used by the World Bank in its Global Development Finance, for example, refers to capital transactions by nonresidents, but excludes assets that give rise to short-term debt. In the IMF Balance of Payment Statistics, capital inflows are the items included in the capital and financial accounts of the balance of payments, comprising mainly credit items (such as debt forgiveness and migrants' transfers) under the heading of "capital transfers", "direct investments" in the country concerned, and the liability items under "portfolio investment" and "other investment" (which includes both short-term and long-term debt in such forms as bank loans, other types of trade credit, and borrowing from IMF).

Capital outflow: This term refers to the acquisition of foreign assets by residents. Sales of foreign assets are defined as a negative capital outflow. Thus the term net capital outflow denotes acquisitions minus sales of foreign assets by residents. In the IMF Balance of Payments Statistics, capital outflows consist of the debit items under the heading of "capital transfers", "direct investment abroad", and the asset items under "portfolio investment" and "other investment".

Net capital flow: This term refers to total net capital inflow less total net capital outflow as defined above. It is positive when net inflows exceed net outflows.

Net transfer: This term refers to net capital inflows less net factor payments abroad; the latter include interest payments on external debt as well as profit remittances. Net transfer is thus a broad measure of a country's capacity to finance its trade deficits. 


\section{Chart 1}

Developing countries: net capital inflows by type of flow, 1975-1998

(Percentage of aggregate net inflow)

1975-1982

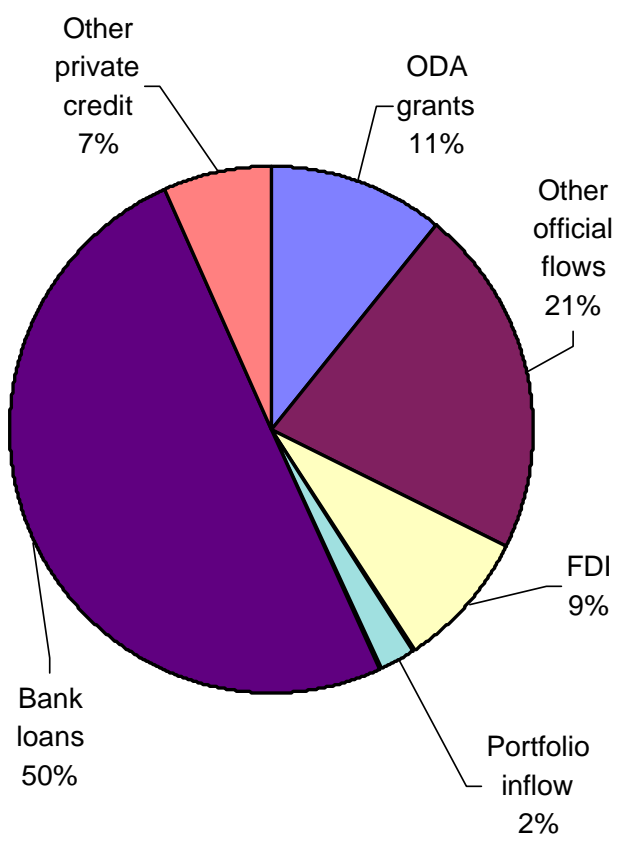

1983-1989

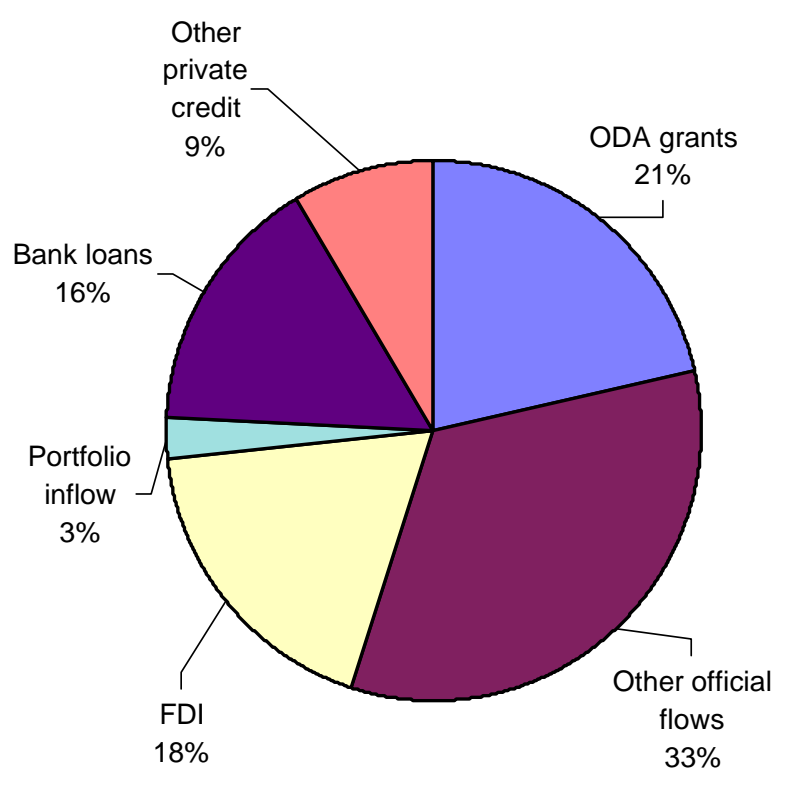

1990-1998

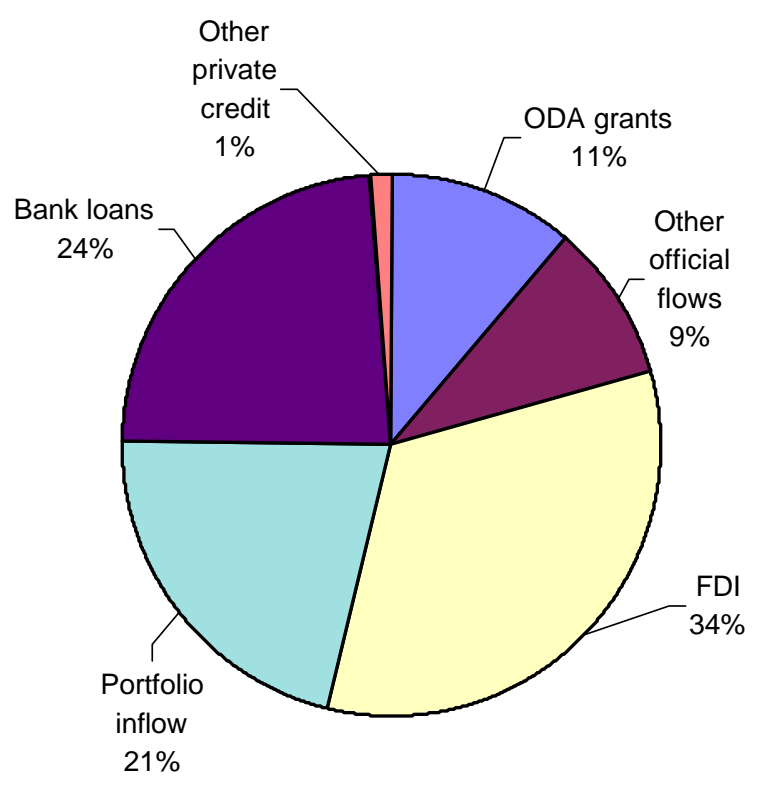

Source and definitions: $\quad$ See table 1. 


\section{Chart 2}

Developing countries: net capital inflow, by region ${ }^{a}$, 1975-1998

(Percentage of aggregate net capital inflow)

1975-1982

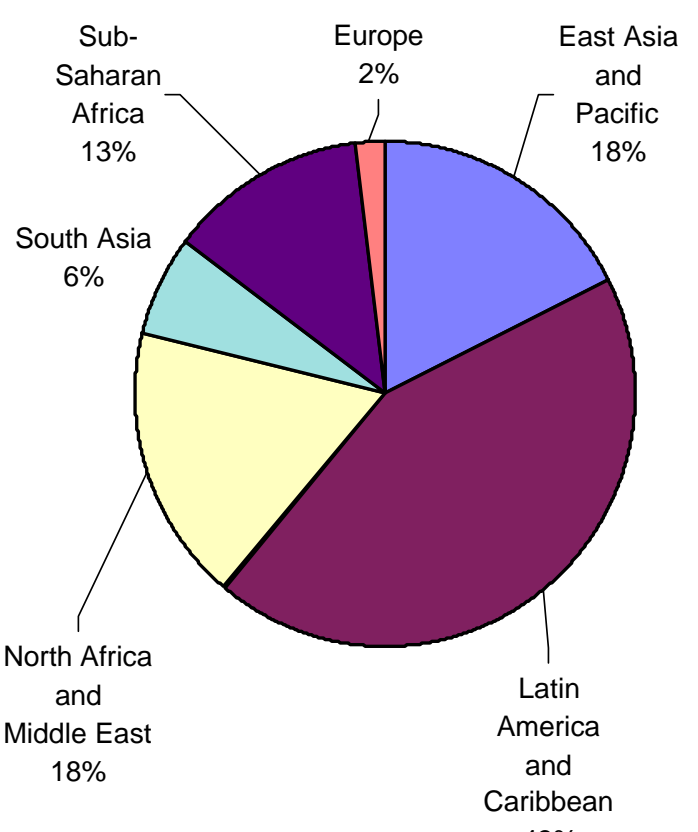

$43 \%$
1983-1989

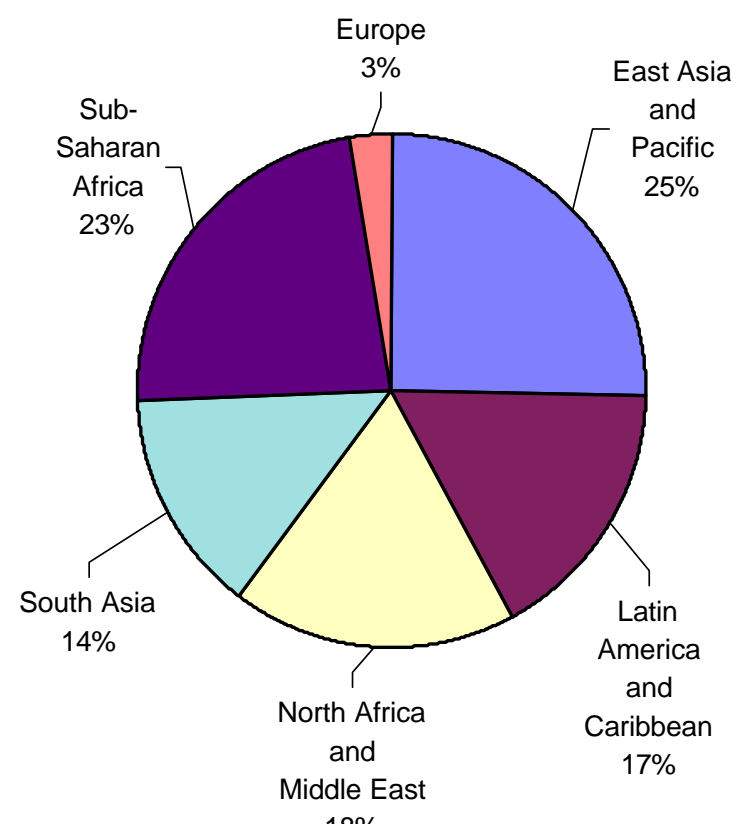

$18 \%$
1990-1998

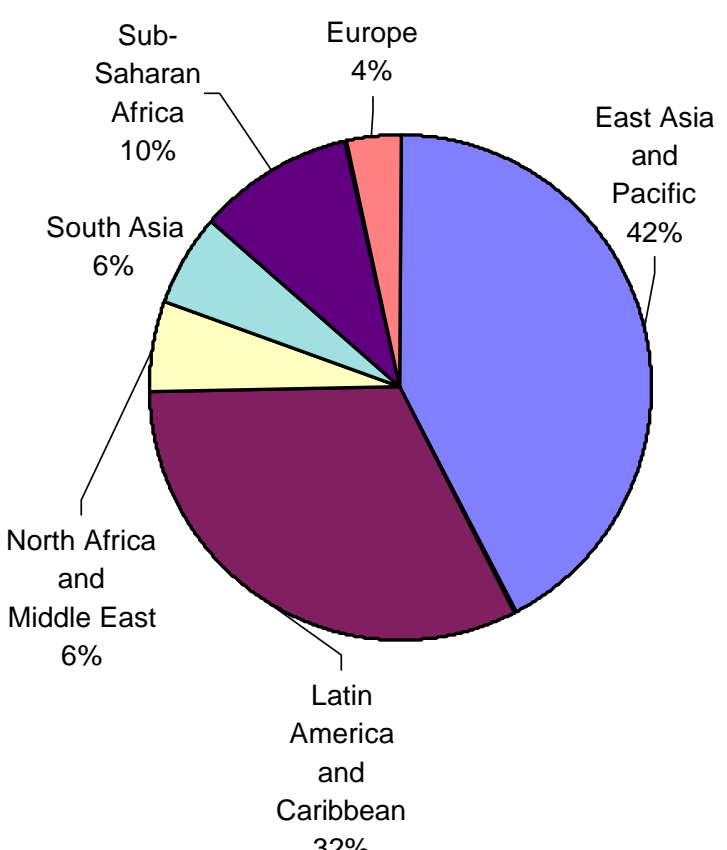

Source and definitions:

See table 1

a Regional classification of the World Bank except for Europe, which comprises Malta and Turkey only. 
trade deficits. These too have remained at about the same level in the 1990s as in the period before the outbreak of the debt crisis.

As shown in chart 1 , there have also been a series of major shifts in the composition of capital inflows since the mid-1970s. From 1975 until the early 1980s, private capital accounted for almost twothirds of total inflows, but after 1982 its share fell to less than 50 per cent not so much because of a rise in official finance as because of a collapse in private inflows, notably international bank lending. In the 1990s the surge in private flows and the decline in official financing have meant that private capital has accounted for 80 per cent of total capital inflows to developing countries. In nominal terms official financing drifted around $\$ 40$ billion, only a little above the levels attained during the years of debt crisis. As shown in chart 2, these changes in the composition of capital inflows as between public and private sources have been accompanied by shifts in their distribution among developing countries and regions. In particular, since official flows tend to favour poorer developing countries and regions, their decline relative to that of private capital flows has been a major determinant of the trend in the share of different groups of developing countries. Thus, the shares of sub-Saharan Africa and South Asia, the major recipients of official finance, increased, while that of Latin America declined sharply after 1982 compared to the pre-debt crisis years owing to the drying-up of private flows. However, during the 1990s the movement has been in the opposite direction, the share of East Asia continuing its rise of the past three decades until the setback of the financial crisis which begun in 1997. The shift in the composition of capital inflows towards private capital has been accompanied by concentration in a small number of developing countries, mainly the so-called emerging markets. ${ }^{17}$ While the 20 countries that constitute this group received, on average, 40 per cent of total net capital inflows during the whole period of the past two decades, their share went up to over 90 per cent in the 1990s, leaving the remaining 10 per cent to be shared among the rest of the developing world.

There has also been a considerable shift in the relative importance of different categories of private inflow. From mid-1970s until the outbreak of the debt crisis of the 1980s bank credits constituted three quarters of total private capital inflows to developing countries, while the rest was accounted for by FDI. This pattern changed drastically after the debt crisis when bank loans collapsed and FDI took the highest share in total private inflows. In the 1990s the revival of bank lending has been concentrated mainly on the Asian emerging markets; FDI has accelerated rapidly and portfolio investment has emerged as a major form of private inflow. These changes have also been associated with the increased share of the private sector as borrower. Before the debt crisis, the share in total external borrowing of private flows not covered by an official guarantee in the recipient country was only about 15 per cent. After 1982 this ratio fell even further before rising rapidly in the 1990s both in absolute terms and in relation to public and publicly guaranteed flows, exceeding the latter from 1995 onwards. However, this trend was 
reversed after outbreak of the East Asian crisis: non-guaranteed borrowing almost disappeared, while public and publicly guaranteed debt shot up, largely as a result of socialization of private debt.

Net capital inflows received by developing countries from non-residents do not necessarily give the amount available for financing current-account deficits and closing resource gaps. Account also needs to be taken of net capital outflows by residents. The importance of capital outflows through acquisition of assets abroad depends, inter alia, on the capital account regime adopted by the countries concerned. During the past 10 years, a growing number of developing countries have liberalized outward capital flows, enabling their residents to shift funds to foreign financial markets for short-term investment as well as for outward FDI and the purchase of long-term financial assets. However, such outflows can also occur under more restrictive capital-account regimes in the form of capital flight. Net capital outflows in fact constitute an increasing part of offsetting financial transactions, as can be seen from table 2. In the emerging markets, for each dollar of net inflow there was a net outflow of 14 cents in the 1980s and one of almost 24 cents in the 1990s, while for developing countries as a whole this share has more than doubled since the beginning of the 1990s. ${ }^{18}$

The coexistence of capital inflows with outflows is a natural outcome of global financial integration. It is a widespread phenomenon in the developed world, reflecting in part the global reach, portfolio diversification and risk management of financial institutions. It can also reflect the disparate behaviour of different categories of financial flows.

Cross-border financial activities have increasingly become a feature of financial institutions in emerging markets. Around 300 banking entities from 10 leading developing countries were operating in OECD countries in 1996 (Cornford and Brandon, 1999: tables 1 and 2). Thus opening of the capital account in emerging markets presents profitable opportunities for portfolio diversification not only for lenders and investors in industrial countries but also for asset holders in these markets themselves. It also allows businesses to take positions abroad in order to hedge against exchange-rate risks. Furthermore, some developing countries have become significant providers of FDI in recent years, with the cumulative outward flow reaching $\$ 52$ billion during 1991-1996, or 21 per cent of total net capital outflows from developing countries (World Bank, 1998: table 1.11). However, an important part of outflows, as of inflows, also consists of liquid capital driven by short-term arbitrage opportunities.

Another important category of offsetting financial transactions is reserve accumulation. During the 1990s more than 20 per cent of total net capital inflows were absorbed by additions to reserves in both developing countries as a whole and in the emerging markets. For the latter there has been a large increase in such additions from a level of only 3 per cent in the 1980s to one similar to the developingcountry average. So long as private capital flows are subject to the control of recipient countries, such flows can be expected to be closely related to imports and current-account financing. The need to 
Table 2

Net capital inflow, current-account and offsetting financial transactions in developing countries and 16 emerging-market countries ${ }^{a}$

\begin{tabular}{|c|c|c|c|c|c|}
\hline & \multicolumn{3}{|c|}{ All developing countries } & \multicolumn{2}{|c|}{ Emerging-market countries } \\
\hline & 1990-1994 & 1995-1998 & 1990-1998 & $1980-1989^{b}$ & 1990-1997 \\
\hline & \multicolumn{5}{|c|}{ Billions of dollars } \\
\hline Net capital inflow & 825.8 & 1064.9 & 1890.6 & 355.3 & 1083.8 \\
\hline Net capital outflow & -142 & -435.3 & -577.2 & -49.6 & -256.2 \\
\hline Net capital flow & 683.8 & 629.6 & 1313.4 & 305.7 & 827.6 \\
\hline BoP errors and omissions & -49.9 & -106.3 & -156.2 & -39.5 & -53.2 \\
\hline Change in reserves ${ }^{c}$ & -221.2 & -216.5 & -437.7 & -10.6 & -231.6 \\
\hline \multirow[t]{2}{*}{ Current-account balance $^{d}$} & -412.7 & -306.8 & -719.5 & -255.6 & -542.7 \\
\hline & \multicolumn{5}{|c|}{ Percentage of net inflow } \\
\hline Net outflow & 17.2 & 40.9 & 30.5 & 14.0 & 23.6 \\
\hline BoP errors and omissions & 6.0 & 10.0 & 8.3 & 11.1 & 4.9 \\
\hline Change in reserves ${ }^{c}$ & 26.8 & 20.3 & 23.2 & 3.0 & 21.4 \\
\hline \multirow[t]{2}{*}{ Current-account balance $^{d}$} & 50.0 & 28.8 & 38.0 & 71.9 & 50.1 \\
\hline & \multicolumn{5}{|c|}{ Percentage of net flow } \\
\hline BoP errors and omissions & 7.3 & 16.9 & 11.9 & 12.9 & 6.4 \\
\hline Change in reserves ${ }^{c}$ & 32.3 & 34.4 & 33.3 & 3.5 & 28.0 \\
\hline Current-account balance $^{d}$ & 60.4 & 48.7 & 54.8 & 83.6 & 65.6 \\
\hline
\end{tabular}

Sources: $\quad$ World Bank, Global Development Finance, 1999 (CD-Rom); IMF, World Economic Outlook, October 1998; IMF, Balance of Payments Statistics, various issues.

Note: For definitions see table 1.

a Argentina, Brazil, Chile, Colombia, Egypt, India, Indonesia, Malaysia, Mexico, Pakistan, Peru, Philippines, Republic of Korea, South Africa, Thailand, Turkey.

b Excluding 1987 and 1988, which were years with current-account surpluses.

c A minus sign indicates an increase in reserves.

$\boldsymbol{d}$ The sum of net capital flow, Balance of Payments Statistics errors and omissions and change in reserves.

maintain a certain level of reserves would then arise from time lags between payments for imports and receipts from exports and from miscellaneous temporary disequilibria in the current balance of payments. Traditionally, reserves covering on average three or four months' imports are considered as adequate for such purposes, and even smaller reserves would be needed to the extent that governments are more willing to respond to current-account disturbances by exchange-rate adjustments. The trend in developing countries has, however, been to accumulate reserves, leading to levels well above the traditional norm. Indeed, despite policy reforms designed to ensure greater flexibility in the adjustment of exchange rates to market conditions, their reserve holdings have tended to rise in both absolute and 
relative terms during the past two decades, a policy involving significant costs. ${ }^{19}$ For the developing countries as a whole, the increase in reserves from 1990 to 1998 amounted to 60 per cent of the total increase in their import bill during the same period.

These increases would appear to be a response to the instability of private capital flows, especially short-term bank loans and much portfolio investment. The instability is exemplified by major constituents of these two categories of external financing for developing countries which displayed much sharper fluctuations during the 1990s than total net capital inflows, increasing more than 2.5 times more rapidly during 1988-1995 but decreasing no less than 83 per cent in 1995-1998, while the total net inflow declined only 12 per cent. Such fluctuations reflect the boom-bust cycle of external financing in the 1990s and the impact of the associated financial crises. ${ }^{20}$

\section{FINANCIAL INSTABILITY AND CRISES}

Since the collapse of the Bretton Woods system increased global capital mobility has been accompanied by greater frequency of financial crises in both developed and developing countries alike. The episodes of financial instability and crisis in industrial countries include the banking and real estate crises in the United States lasting more than a decade from the late 1970s, the major slumps in the global stock market in 1987 and 1989, several episodes of extreme instability in the currency markets of industrial countries of which an outstanding instance was the currency crisis of the European Monetary System (EMS) in 1992, and the ongoing instability in Japanese financial markets that started with the bursting of the bubble in the early 1990s, whilst those in developing countries include the Southern Cone crisis of the late 1970s and early 1980s, the debt crisis of the 1980s, the Mexican crisis of 1994-1995, the East Asian crisis beginning in 1997, the Russian crisis of 1998, and a number of other more limited currency and banking crises. ${ }^{21}$

There are, however, important differences between industrial and developing countries in the nature and effects of financial instability and crises. Experience shows that in developing countries reversal of external capital flows and sharp declines in the currency often threaten domestic financial stability. Similarly, domestic financial crises usually translate into currency turmoil, payments difficulties

\footnotetext{
19 These costs, which are explained in more detail in section IV.B, can be estimated for the additional reserves accumulated by developing countries in 1990-1997 to have amounted to about $\$ 50$ billion (or about 2.5 per cent of total net inflows during the period). See UNCTAD (1999b: 124, footnote 15).
}

\footnotetext{
20 The short-term external financing displaying such higher volatility comprises portfolio investment in equity and short-term debt instruments, such as treasury bills, short-term loans other than trade credits, changes in non-residents' domestic-currency holdings and deposits, and changes in other short-term external liabilities of banks. For a more detailed discussion see UNCTAD (1996b, chap. V, sect. D).
} 
and even external debt crises. By contrast, currency turmoil in industrial countries since the advent of more flexible exchange rates in the 1970s has frequently involved large movements of rates concentrated into short periods. These movements, which result from buying and selling decisions by economic actors in currency markets often taken with little regard for indicators of countries' fundamentals (such as relative price levels, microeconomic performance, and the stance of macroeconomic policies), generally impose costs on the real economy and can lead to significant misalignments, that is to say levels of the exchange rate which, at reasonably full employment for the economy in question, are inconsistent with a sustainable external payments position. ${ }^{22}$ But such turmoil does not usually spill over into domestic financial markets, nor do domestic financial disruptions necessarily lead to currency and payments crises. These differences between developing and developed countries stem from a number of factors. First, the size of developing-country financial markets is small, so that entry or exit of even medium-size investors from industrial countries is capable of causing considerable price fluctuations, even though their placements in these markets account for a small percentage of their total portfolios. Furthermore, differences in the net foreign asset position and the currency denomination of external debt play a crucial role. ${ }^{23}$ Here the vulnerability of developing countries is greater because of their typically higher net external indebtedness and higher shares of their external debt denominated in foreign currencies. The vulnerability of the domestic financial system is increased further when external debt is owed by the private sector rather than by sovereign governments.

A number of common features have marked the history of the post-Bretton Woods crises. First, many of them have been preceded by liberalization of the economy, notably the financial sector. Second, all episodes of currency instability have been started by a sharp increase in capital inflows followed by an equally sharp reversal. Such swings in flows are related to internal or external policy changes that produce divergences in domestic financial conditions relative to those of the rest of the world, often initially reflected in interest-rate differentials and prospects of capital gains. Reversals of capital flows are frequently, but not always, associated with a deterioration in the macroeconomic conditions of the recipient country. This deterioration often results from the effects of capital inflows themselves such as overvaluation of the exchange rate, excessively rapid credit expansion, and speculative bubbles in asset prices. But the deterioration is also generally influenced by external developments affecting interest rates and exchange rates in international markets as much as by shifts in domestic macroeconomic policies. Finally, financial crises tend to be associated more closely with certain types of financial flow and with certain classes of lenders and borrowers than others.

\footnotetext{
22 For two surveys of the voluminous literature on the subject see "The Exchange Rate System" in UNCTAD (1987) and Rosenberg (1996), especially chaps. II and XII (the latter discusses evidence concerning trend - following behaviour of currency traders).

23 Dollarization adds further to vulnerability since it effectively eliminates the difference between residents and non-residents in the determination of the profitability of their investments and their ease of access to foreign assets.
} 
However, currency and financial crises in emerging markets have occurred under varying macroeconomic conditions. They have occurred when current-account deficits were large and unsustainable (Mexico and Thailand), but also when such deficits were relatively small (Indonesia and Russia). Although significant overvaluation has often been characteristic of countries experiencing currency turmoil (Mexico, Russia and Brazil, all of which used the exchange rate as a nominal anchor to bring down inflation), this has not always been the case: for instance, in most East Asian countries the appreciation of the currency was moderate or negligible. Similarly, while in some cases crises were associated with large budget deficits (Russia and Brazil), in others the budget was balanced or in surplus (Mexico and East Asia). Finally, crises occurred when external debt was owed primarily by the public sector (Brazil and Russia) or primarily by the private sector (East Asia).

Financial crises in developing countries are all characterized by a rush of investors and creditors to exit and a consequent financial panic. Indeed, whatever the proximate causes of financial crises or the events that trigger attacks on currencies, international investors and creditors of developing countries tend to manifest herd-like behaviour in exiting as well as in investing or lending. The debt crisis of the 1980s witnessed a drastic cutback in lending by international banks to sovereign debtors, while during the 1995 Mexican crisis the rush for the exits by international creditors took the form of rapid liquidation of government paper and conversion of the proceeds into dollars. Again, in the more recent turmoil in East Asia, the refusal to roll over short-term loans together with the attempt of unhedged debtors to avoid exchange-rate losses were the principal factors deepening the crisis. Creditor overreaction to debtors' financial difficulties is often explained in terms of a collective-action problem. Even though the creditors as a group are better off if they continue to roll over their maturing claims on a debtor, an individual lender or investor has an incentive to exit. Without access to liquidity a debtor entity is then forced to curtail operations or to resort to distress sales of assets, which in turn lower its income and wealth, thereby further constraining its ability to service debt and hence damaging the interests of creditors as a group.

A generalized debt run by international creditors triggered by a loss of confidence can easily turn a liquidity problem into widespread insolvencies and defaults by altering key asset prices, interest rates and exchange rates. In the absence of a large stock of reserves or access to international liquidity, the ability of a debtor developing country to repay its entire stock of short-term external debt on demand is no greater than the ability of a bank to meet a run by its depositors. In the case of bank lending, withdrawal of loans by foreign creditors is likely to trigger a rush by unhedged private debtors into foreign currency as they seek to pay debt or cover their open positions, and may also lead to speculative selling of the currency by residents. This in turn drives down the foreign-exchange value of the domestic currency and raises interest rates, making it more difficult for debtors to service their debt, forcing them to liquidate assets and thereby deepening the debt-deflation process. Debt runs by foreign creditors are often also associated with a flight from non-debt instruments held by both residents and non-residents, 
notably from the equity market. Since such investors face a decline in prices when they attempt to liquidate their holdings, the selling pressure in the currency market may be weakened. Moreover, since they would also suffer from depreciations, they may have less inducement to exit. However, investor overreaction can none the less still amplify destabilizing feedbacks between equity and currency markets.

\section{POLICY RESPONSES}

Some of the possible lines of defence against financial crises involve action at the national level. These include domestic macroeconomic policies, particularly monetary and interest-rate policies, to restore market confidence and halt currency runs, as well as hedging through keeping sufficient foreignexchange reserves and credit lines. Recent experience has pointed to serious weaknesses of macroeconomic policy as a response to currency runs and banking crises. Reliance on foreign exchange reserves and credit lines is likely to be costly and to afford at best partial protection. As a result attention has increasingly turned to structural and institutional weaknesses in the global financial architecture regarding the prevention and management of financial crises, giving rise to an international debate on its reform. Much of this debate has concentrated on five issues, namely (a) transparency, disclosure and early warning systems; (b) financial regulation and supervision; (c) surveillance of national policies; (d) an international lender of last resort; and (e) orderly debt workouts, and these will be the focus of the discussion which follows.

Measures under these headings can help both to prevent and manage financial crises, and a clear distinction cannot always be made between these two objectives. This is true, for example, of banking crises where strengthened financial regulation and supervision are manifestly directed at meeting objectives regarding both prevention and management. It is also true for currency crises where measures such as provision of international liquidity or orderly debt workouts can help to avoid the build-up of external financial fragility and thus to deter attacks on currencies, while at the same time allowing a greater scope for managing such crises and limiting the resulting damage to the economy. Measures can be taken at global, national or regional levels, though not all clearly belong only to one of these levels. Surveillance of national policies, for example, can take place at both the first and the last of the three levels mentioned. Moreover, in the case of policies in areas such as financial regulation and supervision, even though action generally takes place at the national level, in recent years their appropriate design has been increasingly the subject of global or regional initiatives owing to significant cross-border spillovers, free-rider problems, or required restrictions on national policy autonomy. 


\section{A. Monetary policies}

The orthodox policy response to currency turmoil by monetary tightening and high interest rates has not proved effective in recent financial crises. When financial markets panic, the likely effects of such a policy on capital flows tend to be perverse because of the strong adverse influence on credit risk. The withdrawal of foreign lending and flight from the country begin in the first place because lenders and investors do not expect to receive the return on their assets. Higher interest rates simply signal declining creditworthiness and rising default risk, and the expected rate of return adjusted for risk thus tends to fall as interest rates are raised. Even double-digit rates of interest may be unable to persuade people to keep their capital in domestic assets when they believe that such rates are politically difficult to maintain, as was seen in some European countries during the EMS crisis.

If persistently applied, monetary tightening can eventually stabilize the currency by intensifying the difficulties of the debtors and increasing bankruptcies and defaults - that is, by reducing the sales rather than by increasing the purchases of domestic currency. As debt deflation and recession deepen, debtors will become increasingly insolvent and unable to raise funds to purchase foreign exchange to service their debt or to hedge against the exchange-rate risk. However, stabilization of markets by monetary tightening will often be a slow process and will eventually be achieved only by depressing the economy and increasing defaults rather than by bringing back foreign capital.

\section{B. Foreign-exchange reserves and lines of credit}

It has been suggested that debtor countries should maintain adequate reserves to meet their shortterm obligations in order to avoid currency turmoil in the face of a massive withdrawal of foreign loans and investment. Proponents of such a policy point to the experience of economies with large reserves such as Taiwan Province of China, arguing that large reserves would also deter speculative attacks on the currency. However, the consequences of accumulating reserves by borrowing are quite different from accumulating them through trade surpluses. One way of building up such reserves is to sterilize capital inflows through the issue of domestic public debt. However, there is a certain degree of circularity in such a strategy. In effect, it means that a country should borrow short only when it does not use the proceeds of such loans to finance investment and imports. Such a strategy can be very costly to the economy since the return on foreign reserves generally falls short of the cost of external borrowing. Moreover, the cost of sterilizing private borrowing falls entirely on the public sector whose losses will exceed the foreign exchange cost of carrying such reserves since domestic interest rates on 
government debt exceed the rates earned on reserves by a larger margin than borrowing rates in international financial markets. This can give rise to large fiscal deficits. ${ }^{24}$

A variant of this proposal is for the public sector fully to cover the external short-term liabilities of the private sector by borrowing at long-term and investing at short-term abroad. However, not all governments have access to long-term foreign borrowing. More importantly, the cost of such an operation can be very large, particularly when the international long-term rates exceed short-term rates by a large margin and the risk premium on long-term sovereign debt is high. Another strategy would be to maintain credit lines with foreign private banks and to use them when faced with an attack, which is tantamount to arranging a private lender-of-last-resort facility. Again, however, this will work only so long as too large a credit line is not sought. Moreover, the costs involved can be substantial. Finally, there is no guarantee that funds will actually be available when there is a massive withdrawal of foreign lending; and even if they are available, the funds provided may merely offset reduced access to normal credits. $^{25}$

A further problem is that vulnerability to withdrawal of funds is not confined to liabilities in the form of short-term debt. In this respect what matters is the liquidity rather than the maturity of liabilities. As mentioned earlier, massive withdrawal of funds from the equity market can also cause difficulties in the currency market, even though declines in the prices of such assets tend to alleviate pressures on the exchange rate. But the cost of maintaining reserves large enough to meet this eventuality could also be very large.

\section{C. $\quad$ Transparency, disclosure and early warning}

The Asian financial crisis has accelerated initiatives to improve the timeliness and quality of information concerning key macroeconomic variables as well as the financial reporting of banks and non-financial firms. ${ }^{26}$ These are viewed as essential for better decision taking by private lenders and investors, greater market discipline over policy-makers, more effective policy surveillance by multilateral financial institutions, and strengthened financial regulation and supervision.

Regarding key macroeconomic variables, an initiative had already been taken after the Mexican crisis when the IMF established the Special Data Dissemination Standard (SDDS) in April 1996 to guide member countries in the public dissemination of economic and financial information in the context of seeking or maintaining access to international financial markets. At the time it was hoped that the new, more stringent rules associated with the SDDS would serve as an early warning system that would help

\footnotetext{
24 For a more schematic account of the incidence of the cost of such borrowing see UNCTAD (1999b: chap. V, sect. C.2).

$25 \quad$ This possibility is raised in IMF (1999: 33).

26 See, for example, Group of $22(1998 b)$.
} 
to prevent future financial crises. However, in the event the rules did not make such a contribution in the case of the East Asian crisis. In April 1998 the Interim Committee proposed a broadening of the SDDS, clearly inspired in part by what it considered to be the role of informational deficiencies in the East Asian crisis, so that the system would also cover additional financial data such as net reserves (after allowance for central banks liabilities under forward or derivative transactions), private debt (in particular that at short maturities), and other indicators bearing on the stability of the financial sector. At the same time the Interim Committee also asked the IMF to examine the desirability of a code of good practice on transparency with respect to monetary and financial policies which was completed in July 1999 and was adopted in September 1999 by the Interim Committee. ${ }^{27}$ The code identifies practices designed to enhance the transparency, accountability and integrity of the institutions or agencies responsible for the conduct of monetary policy, for financial regulation and supervision, and for oversight of payments systems. Moreover initiatives are under way in the Committee on the Global Financial System with the purpose of exploring ways of improving disclosure by the financial intermediaries involved in international capital flows.

While such initiatives are useful, their impact is likely to be gradual since it will depend to a substantial extent on their success in shaping standards and norms not only of official bodies but also of financial firms, and changes in standards and norms, especially those related to private business operations, frequently require considerable periods of time. Moreover, the potential of such initiatives for preventing financial crises should not be overemphasized. Emphasis on inadequate information as the major reason for failure to forecast the East Asian crisis, for example, appears exaggerated. Although there were some important gaps in information, data were generally available concerning key variables in the countries concerned, such as their balance of payments, both their short- and longer-term external debt and external assets (in particular in the periodic reports of the BIS concerning international bank lending), their capital inflows, the exposure of banks and other financial firms to different sectors or categories of economic activity, and the problems of the property sector. What was missing was adequate evaluation by both multilateral financial institutions and market participants of the implications of available information for countries' ability to continue to obtain funding from the international financial markets. A similar unwillingness to be influenced by available data was evident during the Russian crisis. Much of the increase in the external financial exposure to Russia took place during a period when information was widely available concerning the shortcomings of Russian macroeconomic policy, the weaknesses of the country's banks, and the underdeveloped state of the country's legal and regulatory framework and of its system of corporate governance. Moreover, most of the capital inflows into Russia took place when the country was carrying out IMF stabilization programmes.

\footnotetext{
27 This code is to complement one of good practice on fiscal transparency aimed at strengthening the credibility and public understanding of macroeconomic policies and choices regarding fiscal policies. For a summary of the main features of the code of good practices on transparency in monetary and financial policies and discussion of other current initiatives to strengthen the international financial system, see Drage and Mann (1999: 44-45).
} 
The implicit assumption here appears to be that the deterioration in a debtor country's external payments, net external assets, the growth of domestic credit and so on, will trigger a gradual response and adjustment in the behaviour of lenders and investors, thereby avoiding sudden breaks and panics. But the reality is often that the initial deterioration has little or no effect. Indeed, despite the existence of data and information on such variables, currencies and financial asset prices continue to overshoot their sustainable levels. While the emergence of such misalignments is often a gradual process, spread over a relatively long period of time, their correction is usually compressed into a very short period, and is associated with overshooting in the other direction. Indeed, once the rush to exit has begun, the process itself will lead to a rapid worsening of key indicators and in these circumstances transparency may simply accelerate it. ${ }^{28}$

The East Asian crisis has also focused attention on standards of accounting and financial reporting, particularly those of financial firms. ${ }^{29}$ At first sight recommendations for greater transparency on the part of financial firms have an almost self-evident quality, and the value of improvements in this area seems incontrovertible. Yet on closer scrutiny the issues become less simple. The quality of information made available to financial supervisors has an important bearing on the effectiveness of their work. However, there is less consensus as to the benefits of disclosure to market participants. Public disclosure of information submitted to supervisors is typically subject to limits resulting from belief that it could undermine the confidence in the financial system that regulation is intended to promote, complicate the task of banking supervisors in handling the problems of banks in difficulty, ${ }^{30}$ and enhance rather than diminish the likelihood of increased volatility and instability confronted by financial firms more generally (e.g. Caouette et al., 1998: 409). ${ }^{31}$ Indeed, the Basle Committee on Banking Supervision itself has acknowledged that "there are certain types of information that should be held confidential by banking supervisors" and that "the types of information considered sensitive vary from country to country" (BCBs, 1997: 37).

\footnotetext{
28 The question may be asked, for example, whether disclosure during the spring of 1997 of the accumulation by the Central Bank of Thailand of a large part of the forward-exchange liabilities that depleted its net foreign exchange reserves would have fostered more orderly adjustment or simply have accelerated its currency crisis.
}
29 The improved private-sector transparency for which calls are being made is intended to include not only the reporting of financial firms but also that of non-financial entities. Many of the recommendations under this heading (such as those relating to accounting standards and other disclosures required for shares listed on stock exchanges) refer to both. Financial reporting by several economic sectors is characterized by specificities absent elsewhere, but such specificities are especially important for the financial sector and linked in many ways integrally to its regulation and supervision, the character of which reflects its central role in economies' functioning and stability. In view of their key position in current reform initiatives, the discussion here is limited to the transparency issues involving financial firms.

\footnotetext{
30 Even in the United States, whose banking sector is required to meet relatively high standards of disclosure and where there are growing arguments for increased reliance on disclosure in vetting and disciplining banks, historically "the objective of the bank regulatory agencies has been to preserve the soundness of individual institutions and the integrity of the banking system as a whole. This objective influenced their approach in requiring compliance with disclosure requirements. Generally, the agencies preferred to allow institutions time to resolve financial difficulties. This approach clearly is antithetical to the theory of a marketplace governed by the intense glare of full disclosure" (Arista, 1998: 340).
} 
Despite the widespread acknowledgement of the problems which full disclosure by financial firms may cause, there remains an important school of thought among financial regulators which supports the idea that full disclosure's favourable effects, through its strengthening of market discipline, outweigh its costs. Indeed, according to this view during periods of financial stress lack of information about a bank's exposures to credit and market risks can create a situation in which rumours restrict the willingness of its creditors and counterparties to deal with it, thus threatening not only its survival but possibly also that of other banks which, often also because of inadequate disclosure, appear similar to outsiders (BIS, 1994: para. 2.4).

As in the case of macroeconomic information concerning debtor countries, an implicit assumption of this argument would appear to be that disclosure would make possible the exercise of market discipline in an orderly way which avoided herd-like or panic-stricken reactions on the part of creditors and other counterparties. Such a scenario will undoubtedly apply in some cases. But the outcome will depend on the reactions of different categories of counterparty, some of which have greater access to direct information about a debtor than others, and on different national legal rules and norms. Here too experience shows that there is a danger that initial indications of something amiss may have at most a limited effect but once the climate of opinion among creditors changes, disclosure will simply intensify the debtor's difficulties, thus exacerbating the supervisory problems already mentioned (and possibly posing a threat of broader financial destabilization).

Arguments for full disclosure also raise the question of the value of information made available by financial firms for decisions by supervisors as well as by creditors and other counterparties. Financial liberalization and innovation have greatly increased the speed at which financial firms in many countries can now alter the assets and liabilities on their balance sheets as well as their scope for taking off-balance sheet positions of an opaque nature, thereby changing the risks they face in ways which can be difficult for outsiders to identify. For example, William McDonough, President of the Federal Reserve Bank of New York and current chairman of the Basle Committee on Banking Supervision, has made this point in surprisingly strong terms: “... formerly, you could look at the balance sheet of a financial institution and quickly get a sense of exposure and risks. Today balance-sheet information is clearly inadequate for this purpose ... the fast pace of activity in today's market renders financial statements stale almost before they can be prepared" (Leach et al., 1993: 15-16). These considerations are especially pertinent to banks with substantial trading operations, an increasingly common feature of financial firms.

These limitations of accounting information would apply even if financial firms were fulfilling the requirements of best practice in this area. But in fact there is considerable variation even among industrial countries in both the quantity and form of publicly disclosed information: while arrangements for its provision are widely being strengthened, they frequently fall well short of levels corresponding 
to what is now considered to be best practice. ${ }^{32}$ The point emerges from recent surveys of regimes for financial reporting and the regulatory treatment of loan losses ${ }^{33}$ The information in these surveys, some of which is summarized in table 3 , is not necessarily fully up-to-date, but although the divergence between accepted best practice and national legal regimes may have narrowed since they were undertaken, in many areas it is still likely to be substantial. ${ }^{34}$ Moreover, with regard to the topical subject of banks' trading and derivatives activities the Basle Committee on Banking Supervision and IOSCO have concluded on a series of surveys of the annual reports of a selection of major banks and securities firms that "Despite ... improvements, there remain significant disparities ... as regards the type and usefulness of the information disclosed ... some institutions continue to disclose little, generally, about key aspects of their trading and derivatives activities" (BCBS and IOSCO, 1998: para. 18).

The potential value of the information associated with fuller disclosure for improved surveillance has been a stimulus to econometric analysis of the determinants of currency and banking crises. One of the objectives of this work is the development of leading indicators. Analyses of country risk have long been standard features of the operations of firms and other institutions involved in cross-border lending and investment. ${ }^{35}$ The new econometric work on currency crises represents an attempt to identify more systematically relations between, and the relative importance of, variables traditionally included in analyses of country risk (but often evaluated more informally, for example, on the basis of scoring systems). Work so far $^{36}$ has served to clarify certain issues in international discussion of financial crises but seems more likely to supplement (or serve as an additional input to) pre-existing methods of analysing country risk which, owing to their operational role, must often rely on preliminary, tentative estimates of key variables and inevitably incorporate qualitative evaluation that is specific to particular cases but has an important bearing on the likely actual outbreak of crises. The contribution of econometric work on banking crises can be expected to be similar: here too the discussion of certain issues can be clarified but it is difficult to foresee a situation where such work replaces first-hand (and sometimes confidential) information about the financial sector available to supervisors (and in some cases also to financial firms), and the rapidly proliferating techniques used by both to analyse different types of financial risk. While efforts to develop early-warning indicators of financial crises, like

32 For recommendations as to best practice see BCBS (1998).

33 Ernest and Young (1993), which covers 17 industrial economies as well as Bahrain, Hong Kong (China), Saudi Arabia, Singapore, South Africa and United Arab Emirates; and Price Waterhouse Survey of Bank Provisioning (1995), reproduced as Appendix A of Beattie et al. (1995), which covers 14 industrial countries. The period to which these surveys relate is $1992-1994$.

34 In some countries there may also be divergence between the enunciated standards of the regime for accounting and financial reporting and the actual practice of several financial firms.

35 See, for example, Krayenbuehl (1988: Parts Two and Three), and Caouette et al. (1998: chap. 22).

36 For brief surveys see Goldstein (1998), and Eichengreen and Rose (1998/99). 


\section{Table 3}

Features of financial reporting and supervision for banks in selected economies, $1992^{a}$ and $1994^{a}$

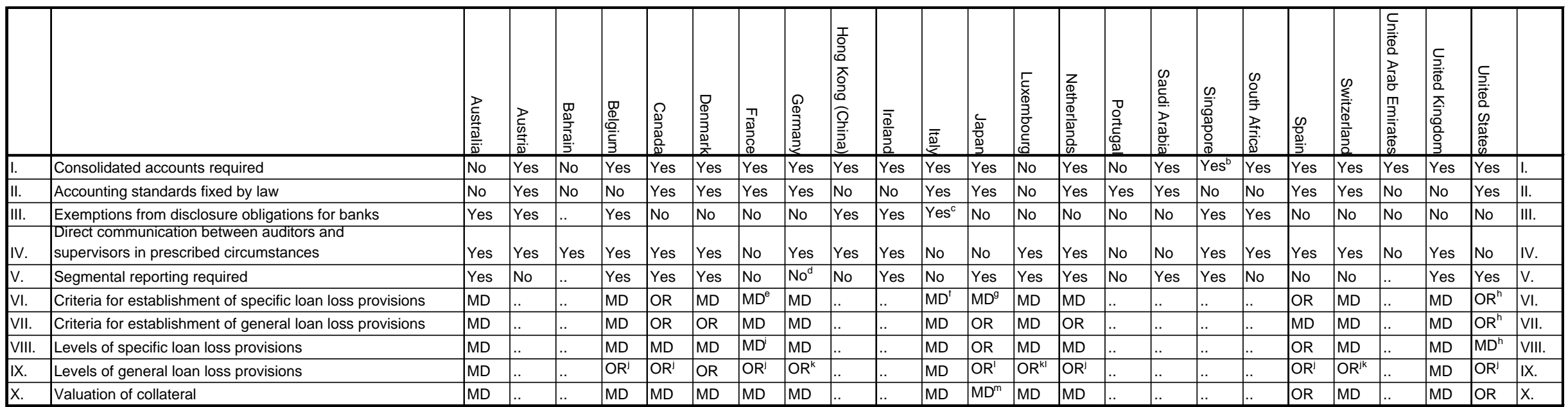

\section{Sources:}

I, II, III, IV and V: Ernst \& Young, International Bank Accounting, 3rd edition (London: Euromoney Publications, 1993); VI, VII, VIII, IX and X: Price Waterhouse Survey of Bank Provisioning, reproduced as appendix A of

V. A. Beattie, P.D. Casson, R.S. Dale, G.W. McKenzie, C.M.S. Sutcliffe and M.J. Turner, Banks and Bad Debts: Accounting for Loan Losses in International Banking (Chichester: John Wiley, 1995).

a 1992: 23 economies (17 industrial, 6 developing); 1994: 14 industrial economies.

b Subject to exemptions for non-banking subsidiaries.

c Reflecting flexibility regarding presentation of accounts.

d Some breakdown of assets and liabilities required.

e Subject to some guidelines of the French Banking Commission.

f Subject to general regulatory guidance.

$g$ Subject to approval of Ministry of Finance.

$\boldsymbol{h} \quad$ Without distinction between specific and general loan loss provisions.

Subject to official guidance as to minimum levels for different categories of loan.

For country risk.

Including rules for hidden reserves.

Including rules set by tax authorities.

m In consultation with Ministry of Finance.

MD: Management's discretion

OR: Official rules.

.. Not available. 
financial firms' and supervisors' techniques for identifying financial risks, are capable of improving policies towards financial crises, there are limits to their effectiveness partly owing to shortcomings of the methods involved and of the information on which they depend, ${ }^{37}$ and also because of limitations of financial regulation and supervision (to which analysis of financial risk is closely connected).

\section{Financial regulation and supervision}

Weak credit evaluation and speculative lending, as well as failure to control currency risk among banks and other financial firms, are often at the origin of financial and currency crises, particularly in emerging markets. There is thus general agreement that regulatory reform is an essential part of the strengthening and restructuring of the financial sector. However, such reform is not a fail-safe way of preventing financial crises, though it can reduce their likelihood and help to contain their effects.

In recent years there has been widespread reform and strengthening of financial regulation at the national level, accompanied by a proliferation of international initiatives to raise regulatory standards and to improve cooperation among supervisors. These processes have been largely driven by concerns raised in relation to financial liberalization and global financial integration. On the one hand, the diversification of their services and the increased competition that are associated with liberalization have exposed financial firms to new levels of risk, which have necessitated overhaul of financial regulation. On the other hand, global financial integration has brought in its train much greater exposure among countries to each other's financial and macroeconomic conditions and increased possibilities for the cross-border transmission of destabilizing influences, while also exposing weaknesses in banking regulation and in cross-border cooperation among banking supervisors.

The main vehicles for international initiatives in financial regulation and supervision have been the Basle Committee on Banking Supervision and other bodies with close links to the BIS as well as other groups concerned with regulatory and accounting standards mentioned above. The initiatives of the Basle Committee have included the adoption of principles designed to ensure that no international bank escapes adequate supervision and the prescription of levels of capital commensurate with the risks that banks run. Agreements under the latter heading were reached concerning credit risks in 1988 (the

\footnotetext{
37 A harsh assessment of efforts to develop early-warning indicators of currency and banking crises has been made by a recent visiting scholar at the IMF as follows: "[Concerns over the adverse impact of financial crises on financial liberalization] have encouraged the official community to invest in early-warning indicators of currency and banking crises in the hope that they will see what is coming. Unfortunately, these models will have about as much success in predicting financial crises as geologists' models have in predicting earthquakes. Earthquakes and financial crises are products of complex nonlinear systems, whose parts interact in unpredictable ways. Consider the following entirely realistic example. The government will devalue the currency only if it fears that the interest rate increases required to defend it will irreparably damage a weak banking system. But the banking system will weaken to this point only if investors withdraw their deposits from the country because they anticipate a devaluation .... Whether speculators attack depends not only on the weakness of a country's banking system but on how much a government cares about further aggravating this problem when deciding whether to defend the currency. And the only thing more difficult to measure than a government's resolve is investors' assessment of it." See Eichengreen (1999: 13).
} 
Basle Capital Accord) and market risks in $1996^{38}$. More recently the Basle Committee has enunciated standards for supervisory practice in its statement, Core Principles for Effective Banking Supervision, the drafting of which involved cooperation with the supervisory authorities of a number of key emerging markets as well as the IMF and the World Bank (BCBS, 1997). The coverage of these Principles includes licensing, various aspects of bank structure, prudential regulation, the methods and powers of supervisors, information requirements, and issues related to cross-border banking. A Core Principles Liaison Group has been established to monitor the implementation and further development of the Principles. In time the Principles can be expected to lead to considerable improvements in regimes of regulation and supervision. But there will still be limits to their effectiveness in preventing financial instability and crises owing partly to almost inevitable imperfections in implementation but also to inherent features of financial regulation (which are discussed at greater length below).

\section{The reform of the Basle Capital Accord}

Developments in the past few years have shown that the standards of the Basle Capital Accord are increasingly divorced from the credit risks actually faced by many banks, and are distorting incentives for banks regarding the capital maintained for a given level of risk. In the context of preventing and managing financial crisis, there is widespread agreement that better control over international inter-bank lending in source countries could contribute to greater global financial stability. However, while the short-term exposure of international banks has been a major feature of recent external debt crises, the Basle Capital Accord attributes a low (20-per-cent) risk weight for the purpose of calculation of capital requirements to claims on banks outside the OECD area with a residual maturity of up to one year and all claims on banks incorporated in the OECD area. This has led to pressure for regulatory changes which would have the consequence of raising the cost to banks of such lending so that they better reflect its risks. Again there are problems due to inappropriate calibration under the Accord of the credit risks of loans to different private borrowers: the same capital charge, for example, is assessed against a loan to a company with an investment-grade rating as to a company with a junkbond one, thereby providing incentives for so-called "regulatory capital arbitrage".

Such concerns underlie the new initiative of the Basle Committee on Banking Supervision to reform the Accord (BCBS, 1999). The approach now envisaged rests on "three pillars": minimum capital requirements, supervisory review of capital adequacy in accordance with specified qualitative principles, and market discipline based on the provision of reliable and timely information. The new proposed capital rules include provision for risk weights for exposure to sovereign entities based on external assessment by rating agencies meeting certain criteria (subject to the country's acceptance of the

38 Credit risk results from the possibility that a bank's counterparty will default on its obligations, and market risk is that of loss due to changes in the market value of a bank's asset before it can be liquidated or offset in some way. 
standards regarding disclosure of the IMF's SDDS) and two possible approaches to weights for interbank exposures, one linking them to the sovereign risk for the country where the bank is incorporated and the other based directly on external ratings of banks themselves. Under the second approach short-term interbank claims might still receive more favourable treatment than those with longer maturities but either approach would be likely to lead to widespread increases in the capital requirements for interbank lending for entities other than those located in countries with the highest credit ratings or in receipt of such ratings themselves.

\section{A World Financial Authority}

The increasingly global character of financial markets and growing links between different categories of financial business have given rise to proposals for the creation of a global mega-agency for financial regulation and supervision or World Financial Authority (WFA). These proposals would appear to be motivated by two arguments. On one argument, since financial businesses are becoming increasingly interrelated and cross-border, their regulation and supervision should also be carried out on a unified and global basis. The other argument focuses on the stability of capital movements under the present patchwork of regimes which only more globally uniform regulation could be expected to control. Various models for a WFA can be envisaged, spanning the spectrum from an institution built on (and thus involved a limited departure from) existing arrangements to one with more comprehensive responsibilities. The more ambitious variant would involve a body with responsibility for setting regulatory standards for all financial enterprises, off-shore as well as on-shore entities (Eatwell and Taylor, 1998a, 1998b). National regulators would remain responsible for implementing standards promulgated by such a WFA, but the new institution could contribute to ensuring their observance through its surveillance since unfavourable public assessments issued by it could be expected to act as a brake on a country's capital inflows. A less ambitious variant for the WFA might serve simply as an umbrella organization into which existing bodies (in some cases with appropriately expanded mandates) would be brought. ${ }^{39}$

While there is considerable scope for strengthening both national regulatory regimes, eliminating their several, often glaring lacunae, and improving cooperation between national supervisors, it is not clear that the more ambitious variant would be a better instrument for this purpose than improvements in the functioning of institutions and modalities already in existence. Such a WFA would have to

\footnotetext{
39 The recently proposed Financial Stability Forum consisting of representatives from the finance ministries, central banks and senior regulatory authorities of the G-7 countries as well as from the IMF, the World Bank, the Basle Committee on Banking Supervision, IOSCO, the International Association of Insurance Supervisors (IAIS), the Bank for International Settlements, the OECD, the Committee on Payment and Settlement Systems, and the Committee on the Global Financial System (formerly the Euro-Currency Standing Committee) is arguably of this kind. Objectives include pooling and sharing of information on vulnerability in the international financial system among different bodies, and some kind of monitoring of the implementation of internationally agreed regulatory and supervisory standards and codes of conduct.
} 
confront the problem of reconciling and integrating the different legal and conceptual frameworks under which supervisors from different backgrounds work. Furthermore, there are no compelling reasons to believe that such a WFA would be more successful than the IMF in achieving stability in financial markets. The legal instruments on the basis of which the WFA would operate would have to be reconciled with the powers of existing institutions, notably the IMF. There is also the matter of how power would be exercised in the new institution and by whom. It is not realistic to envisage that a global institution like a WFA with genuine clout could be established on the basis of a distribution of power markedly different from that of existing multilateral financial institutions. The alternative to a WFA is not an institutional tabula rasa. An, albeit imperfect, network of institutions is already in place, and there can be potential benefits from strengthening it, extending its mandate in certain areas and supplementing it gradually as greater participation is assured and its governance improved.

\section{The limits of prudential regulation}

The continuing incidence of financial instability and crises in industrial countries suggests that regulatory and supervisory reform is unlikely to provide fail-safe protection in this area. And if this statement is true even of countries with state-of-the-art financial regulation and supervision, it is likely to apply a fortiori to most developing and transition economies. These limits to the effectiveness of regulation and supervision have various sources. Firstly, financial regulation is constantly struggling to keep up with financial innovation, and in this struggle it is not always successful. There is thus a continuing danger that new practices or transactions not yet adequately covered by the regulatory framework may prove a source of financial instability. Closely related in many ways to financial innovation are growing difficulties regarding the transparency required for regulation and supervision. As described above, the balance sheets and other returns of many financial firms have an increasingly chameleon-like quality which reduces their value to regulators. The tensions between financial innovation and effective regulation in modern financial markets are unlikely to disappear: one can envisage a tightening of regulation sufficiently drastic to come close to eliminating the dangers due to innovation, but the tightening would probably be too stifling of such innovation to be politically acceptable in any country valuing dynamism in its financial sector.

But perhaps the most fundamental determinant of the limits of regulation and supervision is the susceptibility of most of banks' assets to changes in their quality resulting from changes in economic conditions. No private-sector loan or other asset on a bank's balance sheet should be classified generically as "good". However reasonable the original managerial decision to make a loan and however justified its initial classification as low-risk by banking supervisors, the loan is vulnerable to the 
possibility of an eventual deterioration in its status. ${ }^{40}$ So long as cycles of financial boom and bust are features of the economic system, so also will be unforeseeable deteriorations in the status of many bank assets. During such cycles risks take time to build up and become widely evident. For a while, indeed, the quality of loans can actually be enhanced by the very financing boom of which they are a part. Eventually, the effects of excess capacity generated by the boom and of the over-extended position of financial firms are likely to combine with the factors described in section B to transform the boom into a movement in the opposite direction.

Consequences of such boom-bust cycles can be described in terms of the concept, "latent concentration risk", as used in recent literature on credit risk (Caouette, 1998: 91, 240). Concentration risk is traditionally handled in the context of banking regulation and supervision through limits on the size of exposures to particular borrowers. For this purpose "borrower" is typically defined to include groups of counterparties characterized by links due to common ownership, common directors, crossguarantees, or forms of short-term commercial interdependency. ${ }^{41}$ But boom-bust cycles bring into focus risks due to latent concentration as they lead to deterioration in the economic positions of counterparties apparently unconnected in other, more normal times. Indeed, a common feature of the boom-bust cycle would appear to be exacerbation of the risk of latent concentration as lenders move into an area or sector en masse prior to attempts to exit similarly.

To some extent the risks of latent concentration can be handled through banks' loan-loss provisions and through higher prudential capital requirements for credit risk. But the financing associated with booms in the value of property and other assets are difficult for supervisors to restrain with the measures at their disposal owing to the size of increases in expected income growth or capital gains which are frequently involved. The limits on the crisis-preventing potential of financial regulation are generally recognized by specialists in the field, so that its primary objectives are regarded as having more to do with reducing financial firms' liquidity and solvency problems, protecting depositors, and preventing or mitigating systemic risks due to contagion.

\section{E. Policy surveillance}

In view of the growing size and integration of financial markets, every major financial crisis now has global ramifications. Consequently, preventing a crisis is a concern not only for the country immediately affected but also for other countries. Since macroeconomic and financial policies have a major role in the build-up of financial fragility and emergence of financial crises, global surveillance of 
national policies is called for, with a view to ensuring greater stability and sustainability of exchange rates and external payments positions.

The IMF conducts bilateral surveillance of individual countries' policies through annual Article IV consultations and multilateral surveillance through periodic reviews of global economic conditions in the context of the World Economic Outlook. The failure of IMF surveillance in preventing international financial crises reflects, in part, belated, and so far only partial, adaptation of existing procedures to the problems posed by the large autonomous private capital flows. But perhaps more fundamentally it is due to the unbalanced nature of these procedures, which give too little recognition to the disproportionately large global impact of monetary policies in major industrial countries. International financial crises are often connected with major shifts in macroeconomic indicators external to the countries where the crises first manifest themselves. For example, the origins of the debt crises of the 1980s are to be found in the inconsistencies in policy mix and stances of major OECD countries which resulted in a sharp rise in interest rates in the United States and the appreciation of the dollar. Likewise both the surge in capital inflows and the subsequent outflows associated with the East Asian crisis were strongly influenced by swings in exchange rates and monetary conditions in the United States and other major OECD countries; and shifts in monetary conditions in the United States have played a large role in the fluctuations in private external financing for Latin American countries. ${ }^{42}$

Even though the IMF surveillance, as formally defined, is limited to exchange-rate policies, its scope has tended to broaden over time, so that it now encompasses "all the policies that affect trade, capital movements, external adjustment, and the effective functioning of the international monetary system" (Group of Ten, 1985: para. 40). Given the degree of global interdependence, a stable system of exchange rates and payments positions calls for a minimum degree of coherence among the macroeconomic policies of major industrial countries subject to the proviso that this quest should not lead to a deflationary bias in policies, since, as stated by IMF Article IV, the ultimate objective of policy is to foster "orderly economic growth with reasonable price stability". The existing modalities of IMF surveillance do not include ways of attaining such coherence or dealing with unidirectional impulses resulting from changes in the monetary and exchange-rate policies of the United States and other major OECD countries. In the absence of incentives and enforcement procedures linked to the process of peer review under IMF surveillance, countries elsewhere in the world economy lack mechanisms under the existing system of global economic governance for redress or dispute settlement regarding these impulses. In this respect governance in macroeconomic and financial policies lags behind that for international trade, where such mechanisms are part of the WTO regime. Nor does the Group of 7 provide an effective forum for policy surveillance. Not only does it exclude developing countries but often it also fails to promote policy co-ordination so as to attain exchange-rate stability and growth within

42 Econometric research suggests that internal and external factors were about equally important in the surge in capital flows to Latin America during the early 1990s (Calvo, 1994). 
the industrial world. Broader ad hoc groupings that include emerging markets, such as the Group of 22, cannot be expected to do much better here. Multilateral financial institutions remain the only legitimate and appropriate fora for securing policy consistency and coherence among major industrial countries with a view to their effects on global growth and stability. But if such a function is to be preformed effectively, it is necessary to reform not only surveillance but also the governance of these institutions.

The need for strengthening IMF surveillance in response to conditions produced by greater global financial integration and recurrent crises has been recognized by the Interim Committee in April 1998 which agreed that the Fund "should intensify its surveillance of financial sector issues and capital flows, giving particular attention to policy interdependence and risks of contagion, and ensure that it is fully aware of market views and perspectives". ${ }^{43}$ However, despite the reference to interdependence, it is not evident that these proposals extend to weaknesses arising from the lack of balance in existing procedures. Moreover, even within the current limits of surveillance, the IMF does not have a satisfactory record of diagnosis of build-up of financial fragility and external vulnerability. An important reason is that bilateral surveillance has concentrated on macroeconomic policies, paying little attention to sustainability of private capital inflows and financial sector weaknesses associated with surges in such inflows, in large part because of the faith in financial liberalization and the infallibility of market forces. After the Mexican crisis, the list of developments that may trigger discussions between the Fund and a member country under IMF surveillance of exchange rate policies was extended to include "unsustainable flows of private capital", ${ }^{4}$ but this did not prevent the East Asian crisis. Recent efforts to develop early-warning indicators of banking and currency crises, work to which the IMF has contributed, do not promise radical improvements in the capability of forecasting their outbreak for the reasons given above in section D.3(c).

In future surveillance will need to pay greater attention to unsustainable exchange-rate and payments developments caused by capital inflows, and the Fund's recommendations should include, where needed, control over such inflows. This is quite consistent with the original IMF mandate on surveillance over exchange rate policies, and it is in this context that IMF could be given a mandate over exchange rate policies. Given the difficulties in identifying factors likely to cause financial crises, it may indeed be more prudent to place greater reliance as a matter of course on capital controls and other measures at the national level directed at external assets and liabilities. The effectiveness of IMF surveillance will also depend on the reform of the Fund and its governance structures. Such reform must ensure transparency, accountability and participation.

Certainly there are difficulties in attaining full transparency in surveillance since governments may find objectionable the disclosure of confidential information they provide to the Fund; and owing 
to questions regarding its track record in macroeconomic and financial diagnosis as well as to the political sensitivities involved temptations to turn the Fund into a fully-fledged credit rating agency should also be resisted. Within these limits, however, there is scope to improve the transparency of the IMF. Its prescriptions could be subjected to independent review and the proposal that the United Nations should constitute an IMF External Review Commission is worth pursuing (Sachs, 1998b: 17). Moreover, any extension of the Fund's surveillance should be accompanied by a reform of its voting structure and decision-making procedures to bring about greater participation by developing countries. Quotas, which to a great extent determine voting power and membership rights, need to be revised so that they reflect more accurately relative economic and political power. Different voting structures might also be introduced for different types of decisions. One suggestion is to distinguish between general policy decisions (such as SDR allocations and quotas) and operational decisions related to country programmes, and applying a more democratic voting system to the latter, while maintaining the quota-based system for the former (Woods, 1998: 98, 102). Alternatively, general policy decisions could be transferred to the Interim Committee on a quota-based voting system, while the Executive Board could deal with specific operational decisions through procedures providing for greater participation by its members.

\section{F. $\quad$ An international lender of last resort}

As already noted, currency crises in emerging markets develop as self-fulfilling debt runs, leading to overshooting of exchange rates and translating liquidity into insolvency crises. In view of ineffectiveness of monetary policy in reversing such attacks and the probable inadequacy of reserves and credit lines to meet the resulting demand for foreign currency, there have been calls to establish an international lender-of-last-resort facility in order to provide international liquidity to countries facing financial panic and to support their currencies.

Provision of liquidity to pre-empt large currency swings has not been the international policy response to currency crises in developing countries. Rather assistance coordinated by the IMF has usually come after the collapse of the currency, in the form of bailout operations designed to meet the demands of creditors, to maintain capital-account convertibility, and to prevent default. Moreover, availability of such financing has been associated with policy conditionality that went at times beyond macroeconomic adjustment. ${ }^{45}$ Such bailout operations pose a number of problems. First, they protect creditors from bearing full costs of poor lending decisions, thereby putting the burden entirely on debtors. Moreover, they create moral hazard for international lenders and investors, encouraging imprudent lending practices. Finally, they require increasingly large amounts of financing that have been difficult to raise. These problems could not be evaded in the creation of a genuine international lender 
of last resort. The effective functioning of such a lender depends on two conditions: it should have the discretion to create its own liquidity (or to have unconstrained access to international liquidity), and there should be reasonably well defined rules and conditions that the borrower must meet.

Strictly speaking, the IMF does not satisfy either of the above conditions to qualify as a lender of last resort. ${ }^{46}$ Nonetheless, on the eve of the Mexican crisis the IMF explored the possibility of creating a new "short-term financing facility" (STFF) for this purpose, to be used by countries with close integration with international capital markets, including industrial countries and emerging markets. Although it was not put into practice, discussions concerning the scheme pointed to various problems involved (which were subsequently highlighted during the bailout operations in response to the Mexican and East Asian crises): of special importance in this context were the sheer scale of the financing required (although it was not envisaged that the facility would fully offset financial shocks) and the difficulty of deciding on the terms on which money would be made available. ${ }^{47}$

The SDR might play a key role in the creation of a lender-of-last-resort facility as part of a process of making it a true fiduciary asset and enhancing its role in global reserves. ${ }^{48}$ Recently proposals have been made to allow the Fund to issue reversible SDRs to itself for use in lender-of-last-resort operations, that is to say the allocated SDRs would be repurchased when the crisis was over. ${ }^{49}$ But either approach would probably require an amendment of the Articles of Agreement and could face opposition from some major industrial countries. Even if one were to agree that the IMF could act as an international lender of last resort but without such a capability to create its own liquidity, the Fund would still require access to adequate resources. Since there is agreement that the IMF should remain largely a quota-based institution, funding through bond issues is ruled out. This leaves the Fund's own resources and borrowing facilities (both the $\mathrm{GAB}$ and the $\mathrm{NAB}$ ) as the only potential sources of funding. However, they alone could not provide financing on the scale made available by the IMF and other sources during the Mexican and East Asian crises. On the other hand, even if mechanisms could be put in place to allow the IMF to have rapid access to bilateral funds at times of crisis, it is highly questionable whether the Fund could really act as an impartial lender of last resort in accordance with rules analogous to such operations by national central banks since its decisions and resources would depend on the

\footnotetext{
46 For a more optimistic appraisal of the IMF's potential here see Fischer (1999).

47 This idea actually goes back to the Committee of Twenty. It was revived by the IMF in 1994 and elaborated in a paper by the management (IMF, 1994). For discussions of the issues raised therein see Fitzgerald (1996) and Williamson (1995).

48 A suggestion along these lines was made by the Managing Director of the IMF to the Copenhagen Social Summit in March 1995, when he stated that an effective response to financial crises such as the Mexican one depended on "convincing our members to maintain, at the IMF level, the appropriate level of resources to be able to stem similar crises if they were to occur", adding that this should lead to a decision in favour of "further work on the role the SDR could play in putting in place a last resort financial safety net for the world" (IMF Survey, 20 March 1995).
} 
consent of its major shareholders who are typically creditors of those countries experiencing external financial difficulties.

The terms of access to such a facility pose additional problems. The conditions of lender-of-lastresort financing, namely lending in unlimited amounts and without conditions except for penalty rates, would require much tightened global supervision over borrowers to ensure their solvency, an unlikely development. While automatic access would ensure a timely response to market pressures, it would also create moral hazard for international borrowers and lenders and considerable risk for the IMF. By contrast, conditional withdrawal of financial support would reduce the risk of moral hazard, but negotiations could cause long delays, perhaps leading to deepening of the crisis. It could also lead to irrational and unnecessarily tough conditionality since the countries facing attacks on their currencies would be too weak to resist such conditions.

One way of avoiding these problems might be through pre-qualification: countries meeting certain ex ante conditions would be eligible for lender-of-last-resort financing, with eligibility being determined during Article IV consultations. Access to the lender-of-last-resort facility on a prequalification basis could be subject to limits (for example, as a multiple of country quotas) but, after a crisis occurred, the country might have access to additional funds subject to its commitment to undertake certain actions. However, pre-qualification involves its own set of problems. First, IMF would have to act like a credit-rating agency. Second, the result could be a further segmentation of the Fund's membership, with attendant consequences for its governance. Third, lending at penalty rates might not be enough to avoid moral hazard. Finally, it would be necessary constantly to monitor the fulfilment of the terms of the financing, adjusting them as necessary in response to changes in conditions (which might include those in financial markets or others beyond the control of the government of the recipient country). In these respects difficulties may emerge in relations between the Fund and the member concerned. Such problems are exemplified by the recent Brazilian agreement with the IMF. The Brazilian package might be described as an experiment with the provision of international lender-of-lastresort financing to an emerging market: it was intended to protect the economy against contagion from East Asia, subject to a stringent fiscal adjustment and a gradual depreciation of the real throughout 1999. After a political struggle the Brazilian Government succeeded in passing the legislation needed to meet the fiscal target but, when the currency came under attack, the Fund allowed the agreement to collapse, requiring additional and more stringent conditions regarding the fiscal balance in order to release the second tranche of the package.

The IMF has recently taken steps to strengthen its capacity to provide financing in crises, though this capacity still facts short of that of a genuine international lender of last resort and the terms associated with the new financing are likely to be subject to shortcomings discussed above. The Supplemental Reserve Facility (SRF) approved by the IMF's Executive Board in response to the deepening of the East Asian crisis in December 1997 (and already used in some cases such as that of 
Brazil), provides financing without limit to countries experiencing exceptional payments difficulties but under a highly conditional stand-by or Extended Arrangement. ${ }^{50}$ However, the SRF depends on the existing resources of the Fund which, recent experience suggests, are likely to be inadequate on their own to meet the costs of bailouts. The creation of the Contingency Credit Line (CCL) in April is intended to provide a precautionary line of defence in the form of short-term financing which would be available to meet balance-of-payments problems arising from international financial contagion. ${ }^{51}$ The pressures on the capital account and international reserves of a qualifying country must result from a sudden loss of confidence amongst investors triggered largely by external factors. The terms of the CCL involve elements of pre-qualification as described above: the availability of funds is subject to the country's compliance with conditions related to macroeconomic and external financial indicators and with international standards in areas such as transparency, banking supervision and the quality of its relations and financing arrangements with the private sector. The hope is that the precautionary nature of the CCL will restrict the level of actual drawings, but the danger is that countries will avoid recourse to it, even in the circumstances for which it is intended, owing to fears that it will have the effect of a tocsin in international financial markets, thus stifling access to credit. Moreover, although no limits on the scale of available funds are specified, like the SRF, the CCL will depend on the existing resources of the Fund.

Perhaps a more critical issue is that establishing a genuine international lender of last resort would imply a fundamental departure from the underlying premises of the Bretton Woods system which provided for the use of capital controls to deal with capital flows. In discussion of such a facility its introduction is frequently linked to concomitant arrangements regarding rights and obligations with respect to international capital transactions together with a basic commitment to capital-account liberalization. Even if a properly functioning international lender of last resort could be put in place, it is not clear that this would be the right course of action in response to financial crises and the problems they cause for developing countries.

\section{G. Orderly debt workouts}

Commenting on the debt crisis of the 1980s more than a decade ago, UNCTAD pointed to the circumstance that debtor countries often had to face at and the same time "the financial and economic stigma of being judged de facto bankrupt, with all the consequences that this entails as regards creditworthiness and future access to financing, [while also largely lacking] the benefits of receiving the 
financial relief and financial reorganization that would accompany a de jure bankruptcy handled in a manner similar to chapter 11 of the United States Bankruptcy Code". 52

Chapter 11 procedures are especially relevant to international debt crises resulting from liquidity problems because they are designed primarily to address financial restructuring rather than liquidation. They are based on the premise that the value of the firm as a going concern exceeds the value of its assets in the event of liquidation. Debtors are usually left in possession of their property, and the aim of the procedures is to facilitate orderly workouts in three stages. At the outset procedures allow for an automatic standstill on debt servicing in order to provide the debtors-in-possession with a breathing space from their creditors. The automatic-stay provision is based on the recognition that a "grab race" for assets by the creditors is detrimental to the debtor as well as to the creditors as a group. It allows the debtor the opportunity to formulate a reorganization plan and ensures that creditors are treated equally. Secondly, the Code provides the debtor with access to working capital needed to carry out its operations. A seniority status is granted to debt contracted after the filing of the petition. The final stage is the reorganization of assets and liabilities of the debtor and its operations. The Code discourages holdouts by a certain class of creditors and accelerates the process towards a rapid resolution. The plan does not require unanimous support by the creditors, and the debtor can obtain court approval of the reorganization plans under the "cramdown" provisions. For solvent but illiquid firms, automatic stay and access to new financing may need to be supplemented with an extension of debt maturities. Insolvent firms, on the other hand, would require debt write-downs and conversions, financial and managerial reorganization, and where solvency cannot be restored through such means, liquidation. These procedures are used not only for private debt. Chapter 9 of the Code deals with public debtors (municipalities) and applies the same principles. Similar arrangements exist in most other industrial countries. $^{53}$

Naturally, the application of such principles to cross-border debt involves a number of complex issues. What is under consideration here is not the resolution of individual cases of cross-border claims, but systemic illiquidity problems associated with a generalized rush to exits and run on the currency. Individual debtors may enjoy insolvency protection subject to provisions in their contracts with the creditors, including collective action clauses in bond contracts designed to allow changes in the payment terms. ${ }^{54}$ However, while helpful, under generalized debt runs such provisions do not offer much relief to the country concerned, even if the bulk of the external debt is owed by private banks and firms.

\footnotetext{
52 See UNCTAD (1986: annex to chap. VI). The need for orderly workouts for cross-border claims has subsequently been recognized by many observers, including Sachs (1995), Sachs (1998a), Radelet and Sachs (1998), Group of 22 (1998a), and Eichengreen (1999). For a recent survey of the issues involved see Radelet (1999).

53 For a comparison between the United States, the United Kingdom and German bankruptcy codes see Eichengreen and Portes (1995), and Franks (1995).

54 Even in individual cases, the application of such provisions involves a number of complex legal questions, such as the determination of the relevant law and forum, and enforcement. See, for example, Sassoon and Bradlow (1987).
} 
When there are numerous debtors, it is very difficult to activate appropriate procedures simultaneously for all so as to halt the run on the currency. More importantly, as in East Asia, most private debtors may indeed be solvent, but the country may not have the reserves to meet the demand for foreign exchange. However, as noted above, debt runs can make such debtors insolvent, and this danger is greater when external debt is owed by the private sector and exchange controls have been dismantled. Thus the task of stemming runs on the currency falls on the governments of debtor countries.

Current judicial practices and government policies in the major industrial countries do not allow debtor governments to benefit from standstill provisions regarding their external debt. In this context, a question arises as to whether the provisions of the Articles of Agreement of the IMF can provide a statutory basis for action by debtor governments through exchange controls. The most relevant provisions are in article VIII, section 2(b): "Exchange contracts which involve the currency of any member and which are contrary to the exchange control regulations of that member maintained or imposed consistently with this Agreement shall be unenforceable in the territories of any member. In addition, members may, by mutual accord, cooperate in measures for the purpose of making the exchange control regulations of either member more effective, provided that such measures and regulations are consistent with this Agreement". This Article has given rise to a number of conflicting interpretations as to the latitude it provides for governments to impose standstills on payment of external obligations. In practice governments are reluctant to resort to unilateral suspension of debt servicing and exchange controls even in the extreme event of financial panic since, as recognized by the IMF, "there exists no well-defined and accepted legal process that is applicable in such cases", so that "the process of debt resolution by involuntary restructuring is necessarily ad hoc with uncertain outcome" and "involuntary debt restructuring will damage creditworthiness and may increase the cost of accessing international markets in the future" (IMF, 1995: 11).

In view of the deficiencies of current institutional arrangements for dealing with debt crises, and the increased capacity of financial markets to inflict serious damage, there is now a growing recognition of the need for reform. One proposal is to create an international bankruptcy court in order to apply an international version of chapter 11 (or chapter 9) drawn up in the form of an international treaty ratified by all members of the United Nations (Raffer, 1990). A less ambitious and perhaps more feasible option would be to establish a framework for the application to international debtors of key insolvency principles, namely debt standstill and debtor-in-possession financing, and to combine them with the established practices for restructuring debt.

On one view, under such a framework standstills would need to be sanctioned by the IMF: "upon determination by the Executive Board of the IMF, the debtor government would be protected from legal challenges by its creditors for immediate debt collection" (Sachs, 1988a: 52). It has in fact been suggested that "a definitive interpretation of article VIII (2) (b) would support the IMF in this role even if it did not have legal effect in national courts" (Eichengreen and Portes, 1995: 50). The Canadian 
Government has gone further, proposing an Emergency Standstill Clause to be mandated by IMF members. ${ }^{55}$ However, it would be difficult to avoid delays and panics in any procedure requiring prior consultations with the Fund. Moreover, there is a problem of conflict of interest. The Executive Board of the IMF is not a neutral body which could be expected to act as an independent arbiter, because countries affected by its decisions are also among its shareholders. Besides the Fund itself is a creditor and a source of new money. An alternative procedure would be to allow countries meeting certain ex ante criteria during Article IV consultations to have the right to impose standstills should their currencies come under attack. This would be similar to pre-qualification in lender-of-last resort financing discussed above, and while such a procedure would suffer from the same drawbacks, it would certainly be superior to a procedure entailing lengthy ex post negotiations with the IMF.

Under another alternative, which is free of the objections to procedures involving sanction by the IMF, the decision for standstill could be taken unilaterally by the debtor country and then submitted to an independent panel for approval within a specified period. Its ruling would need to have legal force in national courts for the debtor to enjoy insolvency protection. Such a procedure would in important respects be similar to WTO safeguard provisions allowing countries to take emergency actions. ${ }^{56}$

Recognizing the difficulties in establishing internationally agreed standstill provisions, emphasis has been placed, notably by the Group-of-22 Working Group, on voluntary mechanisms. ${ }^{57}$ The dilemma here is that the need for mandatory provisions has arisen precisely because voluntary approaches have not worked in stemming debt runs. On the other hand, while a number of proposals have been made to introduce mechanisms to provide automatic triggers, such as comprehensive bond covenants or debt roll-over options designed to enable debtors to suspend payments, these are unlikely to be introduced voluntarily and would need an international mandate. ${ }^{58}$ Thus, in the absence of a genuine lender of last resort, an internationally agreed standstill would appear to be the only effective mechanism to stop selffulling debt runs.

If they are to have the desired effect on currency stability, debt standstills should be accompanied by temporary exchange controls over all capital-account transactions by residents and non-residents alike. There would also be a need to combine debt standstills with debtor-in-possession financing in

\footnotetext{
55 Department of Finance, Canada (1998).
}

56 The GATT includes provisions for various kinds of safeguard measures. For example, under the heading of safeguarding a country's external financial position or balance of payments, import restrictions may be imposed to forestall a serious decline in foreign exchange reserves or (in the use of a developing country) to ensure a level of reserves adequate for implementation of its programme of economic development. Moreover, safeguard action is also possible in the form of suspension by a country of its obligations under the agreement to protect a sector from serious injury caused or threatened by increases in imports. For more detailed discussion see Jackson (1997: chap. 7).

57 See Group of 22 (1998a: sect. 4.4) and the thrust of the discussion on facilitating the private sector's involvement in forestalling and resolving financial crises in IMF (1999: 9-24).

58 Concerning the difficulty of achieving changes in this area voluntarily see Eichengreen (1999: 66-69). For the proposal that all lending in foreign currencies include a "universal debt roll-over option with a penalty" to enable the borrower at his own discretion to roll over such debt for a specified period (Buiter and Silbert, 1998). 
order to replenish the reserves of the debtor country and provide working capital. This would mean IMF "lending into arrears". The funds required for such emergency lending would be much less than the scale of bailout operations. Moreover, the Fund could also help arrange emergency lending from private capital markets with seniority status.

Legally sanctioned standstills would facilitate debt restructuring negotiations. For sovereign debt to private creditors, reorganization could be carried out through negotiations with the creditors, and the IMF could be expected to continue to play an important role by providing a forum for negotiations between creditors and debtor governments. Special arrangements would be needed for bonds, and the covenants mentioned above would facilitate their restructuring.

For private debtors, government involvement in negotiations would be inevitable when the stability of the domestic banking system was at stake. In past episodes of crisis, negotiated settlements often resulted in the socialization of private debt when the governments of developing countries were forced to assume loan losses. ${ }^{59}$ Such practices are not consistent with bankruptcy principles and make restructuring more difficult. The introduction of an internationally sanctioned automatic stay, together with debtor-in-possession financing, could help to relieve such pressures. Judicial procedures could be applied to individual debtors according to the law and the forum governing the contracts at issue. Their application would be greatly facilitated by the existence of proper bankruptcy procedures in debtor countries. Indeed, it would be in the interest of those countries lacking such procedures to establish domestic insolvency regimes in order to allow an orderly resolution of debt crises and to reduce their likelihood by reducing uncertainties and raising confidence.

Writing such a standstill mechanism into the rules and conditions governing international financial contracts would mean that lenders and investors knew in advance that they might be locked in, should a financial panic develop and a country's currency come under attack. This should promote a better assessment of risks, eliminate moral hazard, and reduce purely speculative short-term capital flows to emerging markets. It would also eliminate the need for large-scale bailouts. Together with IMF lending into arrears, it would prevent an unnecessary squeeze on the economy and collateral damage for firms and other economic agents bearing no responsibility for the financial crises, while allowing the country breathing space to design and negotiate an orderly debt reorganization plan. Overall, such orderly work-out procedures would promote greater stability and contribute to a more equitable allocation of the costs of a crisis between lenders and borrowers.

\footnotetext{
59 For example, in the restructuring of the bank debt of the Republic of Korea in January 1998 private debts "effectively became nationalized via a guarantee by the Korean Government .... Creditors, for their part, came out better after the rollover than before: there was no writedown, the new loans carried higher interest rates than the original loans". See Radelet (1999: 11). Similarly, in the Chilean debt crisis of the early 1980s private debts were included in debt rescheduling negotiated between the Chilean Government and its foreign bank advisory committee, apparently as a result of pressure from this committee including a tightening of the terms on short-term trade credits (Diaz Alejandro, 1985: 12).
} 


\section{CONCLUSIONS}

Given the inherent instability of international capital movements, recent experience shows that any country closely integrated into the global financial system is susceptible to financial crises and currency turmoil. Developing countries are particularly vulnerable owing to their dependence on foreign capital and their net external indebtedness. Indeed, the recent bouts of crisis in emerging financial markets have pointed to the limits of national policy responses for dealing with such crises and have provoked widespread agreement that there are structural and institutional weaknesses regarding their prevention and management. Since systemic deficiencies in the current regime for capital flows and exchange rates regularly give rise to costly financial crises in developing countries regardless of institutional and policy differences amongst them, for such countries global financial reform is an issue deserving top priority.

In an ideal world global arrangements designed for the prevention and management of financial instability and crises would include (a) some combination of disclosure and transparency by both public and private institutions, (b) effective surveillance over national macroeconomic and financial policies, (c) globally agreed but nationally implemented rules for the control of capital flows through oversight of international lenders and borrowers, (d) an lender of last resort with discretion to create its own liquidity, and (e) orderly debt work-out procedures in international finance.

However, such a world is still a remote prospect. So far, efforts to redesign the financial architecture have been hostage to disagreements among the G-7 countries. The case for improved disclosure and transparency is now widely accepted, as is that for strengthened financial regulation and supervision. Indeed, in both cases the potential benefits, while real, are often exaggerated. But there is more resistance to reform of multilateral surveillance over monetary and exchange-rate policies of the major industrial countries, and prospects for curbing financial instability through global rules and controls over international capital movements are equally bleak. There is also unwillingness to establish a genuine international lender of last resort. Instead, the tendency is to introduce solutions involving limited increases in the availability of external financing designed to impose discipline on debtor countries and to keep them on a short leash. By contrast, political support is growing in the major industrial countries for more orderly debt work-out procedures, and for involving the private sector in the resolution of financial crises.

Thus, in the current political environment a feasible strategy offering considerable potential benefits to developing countries in their search for greater financial stability would involve preservation of the principle of national control over capital flows together with internationally agreed arrangements for debt standstills and lending into arrears. This emphasis on the importance of continuing national policy autonomy is linked to various features of the earlier discussion of this paper. Ways have not yet been found at a global level to eliminate the cross-border transmission of financial shocks associated 
with greater global financial integration or other pressures connected with capital movements which are capable of triggering financial crises. And the international financial system will continue to be affected in unpredictable ways by ongoing technological and transactional innovation, so that any international regime involving substantial constraints on policy autonomy regarding the capital account of the balance of payments risks being overtaken by changes requiring new policy responses. The need for this autonomy is an argument against international agreements on capital-account convertibility, international investment, or wholesale liberalization of financial services. It also points to caution regarding the attribution of additional powers over international capital movements to existing global financial institutions (or to possible new ones which can be envisaged) owing to domination by countries with strong vested interests in further financial liberalization. 


\section{REFERENCES}

AHLUWALIA, M.S. (1999), “The IMF and the World Bank: are overlapping roles a problem?”, in UNCTAD (1999c).

AKYÜZ, Y. and A. CORNFORD (1994), "Regimes for international capital movements and proposals for reform", UNCTAD Discussion Paper No. 83 reprinted as "International capital movements: some proposals for reform", chapter 7 of Michie and Grieve Smith (1995).

BIS (1994), Public Disclosure of Market and Credit Risk by Financial Intermediaries, a discussion paper proposed by a Working Group of the Euro-currency Standing Committee of the Group of Ten Countries (Basle: Bank for International Settlements).

BCBS (1991), Measuring and Controlling Large Credit Exposures (Basle: Basle Committee on Banking Supervision).

BCBS (1997), Core Principles for Effective Banking Supervision (Basle).

BCBS (1998), Enhancing Bank Transparency: Public Disclosure and Supervisory Information that Promote Safety and Soundness in Banking Systems (Basle).

BCBS (1999), A New Capital Adequacy Framework, consultative paper issued by the BCBS (Basle).

BCBS and IOSCO (1998), Trading and Derivatives Disclosures of Banks and Securities Firms, Joint Report by the BCBS and the Technical Committee of the International Organizations of Securities Commissions (IOSCO) (London and Washington, D.C.).

BEATTIE V.A., P.D. CASSON, R.S. DALE, G.W. MCKENZIE, C.M.S. SUTCLIFFE and M.J. TURNER (1995), Banks and Bad Debts: Accounting for Loan Losses in International Banking (Chichester, etc.: John Wiley).

BUITER, W. and A. SILBERT (1998), "UNDROP or Your Drop: a small contribution to the New International Financial Architecture", mimeo, November.

CALVO, G.A. (1994), “The management of capital flows: domestic policy and international cooperation”, in UNCTAD (1994).

CAOUETTE, J.B., E.I. ALTMAN and P. NARAYANAN (1998), Managing Credit Risk: the Next Great Financial Challenge (New York, etc.: John Wiley).

CORNFORD, A. (1996), “The Tobin tax: a silver bullet for financial volatility, global cash cow or both?”, UNCTAD Review.

CORNFORD, A. and J. BRANDON (1999), "The WTO Agreement on Financial Services: problems of financial globalization in practice" in UNCTAD (1999a).

DEPARTMENT OF FINANCE (Canada) (1998), “Canada's six point plan to restore confidence and sustain growth”, mimeo., September.

DRAGE, J. and F. MANN (1999), "Improving the stability of the international financial system", Financial Stability Review, No. 6 (June).

D'ARISTA, J.W. (1994), The Evolution of U.S. Finance. Volume II: Restructuring Institutions and Markets (Armonk, N.Y.: M.E. Sharpe, 1994).

DIAZ ALEJANDRO, C. (1985), “Good-bye financial repression, hello financial crash”, Journal of Development Economics, 19 (1/2) (September-October). 
EATWELL, J. and L. TAYLOR (1998a), “The case for a World Financial Authority”, mimeo.

EATWELL, J. and L. TAYLOR (1998b), "International capital markets and the future of economic policy", CEPA Working Paper No. 9 (September).

EDWARDS, R.W. (1985), International Monetary Collaboration (Dobbs Ferry, N.Y.: Transnational Publishers).

EICHENGREEN, B. (1999), Towards a New Financial Architecture: a Practical Post-Asia Agenda (Washington, D.C.: Institute for International Economics).

EICHENGREEN, B. and R. PORTES (1995), What Crises? Orderly Workouts for Sovereign Debtors (London: Centre for Economic Policy Research).

EICHENGREEN, B. and A.K. ROSE (1998/99), "The empirics of currency and banking crises", NBER Reporter, Winter.

ERNST and YOUNG (1993), International Bank Accounting (3rd edition) (London: Euromoney Publications).

EZECHIEL, H. (1998), "The role of Special Drawing Rights in the International Monetary System", in UNCTAD (1998b).

FELDSTEIN, M. (1998), “Refocussing the IMF”, Foreign Affairs, vol. 77, No. 2 (March/April).

FISCHER, S. (1999), "On the need for an international lender of last resort", http://www.inf.org/external/np/speeches/1999.

FITZGERALD,E.V.K. (1996), "Intervention vs regulation: the role of the IMF in crisis management and prevention", UNCTAD Review.

FRANKS, J. (1995), "Some issues in sovereign debt and distressed reorganization", in Eichengreen and Portes (1995).

GOLDSTEIN, M. (1998), "Early warning indicators of currency and banking crises in emerging economies", in Financial Crises and Asia, CEPR Conference Report No. 6 (London: Centre for Economic Policy Research).

GRAHAM, B. (1944), World Commodities and World Currencies (New York and London: McGraw-Hill Book Company).

GROUP OF TEN (1985), "The functioning of the international monetary system", a report to the Ministers and Governors by the Group of Deputies (Washington, D.C.).

GROUP OF 22 (1998a), Report of the Working Group on International Financial Crises, mimeo. (Washington, D.C.).

GROUP OF 22 (1998b), Report of the Working Group on Transparency and Accountability, mimeo. (Washington, D.C.).

IMF (1994), “A short-term financing facility” (Washington, D.C., IMF, September).

IMF (1995), International Capital Markets: Developments, Prospects and Policy Issues, World Economic and Financial Surveys (Washington, D.C.: IMF).

IMF (1999), Involving the Private Sector in Forestalling and Resolving Financial Crises (Washington, D.C., IMF).

JACKSON, J.H. (1997), The World Trading System: Law and Policy of International Economic Relations, 2nd edition (Cambridge, Mass. and London: The MIT Press).

KALDOR, N. (1964), Essays on Economic Policy, volume II (London: Gerald Duckworth). 
KALDOR, N., HART A.G. and TINBERGEN J., "The case for an international commodity reserve currency", in Kaldor (1964).

KRAYENBUEHL, T. (1988), Country Risk: Assessment and Monitoring (Cambridge: Woodhead-Faulkner).

LEACH, J.A., W.J. McDONOUGH, D.W. MULLINS and B. QUINN (1993), "Global derivatives: Public sector responses", Occasional Paper No. 44 (Washington, D.C.: Group of Thirty).

MASON, S.P., R.C. MERTON, A.F. PEROLD, P. TUFANO (1995), Cases in Financial Engineering: Applied Studies of Financial Innovation (Englewood Cliffs: Prentice Hall).

MICHIE, J. and J. GRIEVE SMITH (ed.) (1995), Managing the Global Economy (Oxford: Oxford University Press).

OECD (1990), Liberalization of Capital Movements and Financial Services in the OECD Area (Paris: OECD).

PRICE WATERHOUSE (1995), Price Waterhouse Survey of Bank Provisioning, in Beattie et al. (1995).

RADELET, S. (1999), “Orderly workouts for cross-border private debt”, in UNCTAD (1999c).

RADELET, S. and J. SACHS (1998), “The East Asian financial crisis: diagnosis, remedies and prospects”, Brookings Papers on Economic Activity, No. 1.

RAFFER, K. (1990), "Applying chapter 9 insolvency to international debts: an economically efficient solution with a human face", World Development, vol. 18, no. 2.

ROSENBERG, M.R. (1996), Currency Forecasting: A Guide to Fundamental and Technical Models of Exchange Rate Determination (Chicago, etc.: Irwin).

SACHS, J. (1995), "Do we need an international lender of last resort?", Frank D. Graham Lecture, Princeton University.

SACHS, J. (1998a), "External debt, structural adjustment and economic growth", in UNCTAD (1998b).

SACHS, J. (1998b), "Proposals for reform of the Global Financial Infrastructure", paper presented to the UNDP meeting on the Reform of the Global Financial Infrastructure, December (New York).

SASSOON, D.M. and D. D. BRADLOW (ed.) (1987), Judicial Enforcement of International Debt Obligations (Washington, D.C.: International Law Institute).

UL HAQUE, M., I. KAUL and I. GRUNBERG (1996), The Tobin Tax: Coping with Financial Volatility (New York and Oxford: Oxford University Press).

UNCTAD (1986), Trade and Development Report, 1986 (New York: United Nations).

UNCTAD (1987), International Monetary and Financial Issues for Developing Countries (New York: United Nations).

UNCTAD (1994), International Monetary and Financial Issues for the 1990s. Vol. IV (New York and Geneva: United Nations).

UNCTAD (1995), International Monetary and Financial Issues for the 1990s. Vol V (New York and Geneva: United Nations).

UNCTAD (1996a), UNCTAD Review (Geneva: UNCTAD).

UNCTAD (1996b), Trade and Development Report, 1996 (New York and Geneva: United Nations).

UNCTAD (1998a), Trade and Development Report, 1998 (New York and Geneva: United Nations).

UNCTAD (1998b), International Monetary and Financial Issues for the 1990s. Vol. IX (New York and Geneva: United Nations). 
UNCTAD (1999a), International Monetary and Financial Issues for the 1990s. Vol. X (New York and Geneva: United Nations).

UNCTAD (1999b), Trade and Development Report, 1999 (New York and Geneva: United Nations).

UNCTAD (1999c), International Monetary and Financial Issues for the 1990s. Vol. XI (New York and Geneva: United Nations).

United Nations (1999), Towards a New International Financial Architecture, Report of the Task Force of the United Nations Executive Committee of Economic and Social Affairs, January.

WILLIAMSON, J. (1977), The Failure of World Monetary Reform, 1971-74 (Sunbury-on-Thames, etc.: Thomas Nelson).

WILLIAMSON, J. (1995), “A new facility for the IMF”, in UNCTAD (1995).

WOODS, N. (1998), "Governance in international organizations: the case for reform in the Bretton Woods institutions", in UNCTAD (1998b).

WORLD BANK (1998), Global Development Finance, 1998 (Washington, D.C.: The World Bank). 
No. 56, March 1993

No. 57, April 1993

No. 58, April 1993

No. 59, May 1993

No. 60, July 1993

No. 61, July 1993

No. 62, July 1993

No 63, July 1993

No. 64, July 1993

No. 65, August 1993

No. 66, August 1993

No. 67, September 1993

No. 68, September 1993

No. 69, September 1993

No. 70, October 1993

No. 71, October 1993

No. 72, October 1993

No. 73, November 1993

No. 74, November 1993

No. 75, November 1993

No. 76, December 1993

No. 77, January 1994

No. 78, January 1994

No. 79, February 1994

No. 80, February 1994
Yilmaz AKYÜZ

Alice H. AMSDEN

Celso ALMEIDA

Ali-Reza NIKPAY

Jean-Marc FONTAINE

Korkut BORATAV

Roberto FRENKEL

Machiko NISSANKE \& Priya BASU

Machiko NISSANKE \& Priya BASU

Ercan UYGUR

Yilmaz AKYÜZ

Cem SOMEL

Andrew CORNFORD

Sebastian SCHICH

Veena JHA,

René VOSSENAAR \&

Simonetta ZARRILLI

Adolfo CANITROT

Xiaoning J.ZHAN

J.H. REICHMAN

Priya BASU \& Norman GEMMELL

William W.F. CHOA

Ajit SINGH

Shigehisa KASAHARA

Jean K. THISEN

Kálmán KALOTAY \& Ana María ALVAREZ

Edouard DOMMEN
Financial liberalization: The key issues

Structural macroeconomic underpinnings of effective industrial policy: Fast growth in the 1980s in five Asian countries

Development and transfer of environmentally sound technologies in manufacturing: A survey

Privatization in Eastern Europe: A survey of the main issues

Reforming public enterprises and the public sector in sub-Saharan Africa

Public sector, public intervention and economic development

Growth and structural reform in Latin America: Where we stand

Mobilization and allocation of domestic savings: A study on Bhutan

Mobilization and allocation of domestic savings A case study on Nepal

Liberalization and economic performance in Turkey Maastricht and fiscal retrenchment in Europe

The State in economic activity: Problems of economic policy-making

The role of the Basle Committee on Banking Supervision in the regulation of international banking

The level and volatility of external financial positions and the costs of export credit insurance

Ecolabelling and international trade

The exchange rate as an instrument of trade policy

North American economic integration and its implications for the exports of China and Hong Kong

Implications of the Draft TRIPS Agreement for developing countries as competitors in an integrated world market

Fiscal adjustment in the Gambia: A case study

The relevance of market structure to technological progress: A case study of the chemical industry

The Plan, the market and evolutionary economic reform in China

A rescue plan for the post-bubble Japanese economy: The establishment of the Cooperative Credit Purchasing Company

The European Single Market and its possible effects on African external trade

Emerging stock markets and the scope for regional cooperation

Développement durable: Mots-déclic 
*No. 81, March 1994

No. 82: WITHDRAWN

No. 83, May 1994

No. 84, May 1994

No. 85, July 1994

No. 86, July 1994

No. 87, July 1994

No. 88, August 1994

*No. 89, September 1994

No. 90, October 1994

No. 91, October 1994

No. 92, November 1994

No. 93, December 1994

No. 94, January 1995

No. 95, January 1995

No. 96, February 1995

No. 97, February 1995

No. 98, April 1995

No. 99, May 1995

No. 100, August 1995

No. 101, August 1995

No. 102, August 1995

No. 103, September 1995

No. 104, September 1995

No. 105, October 1995

No. 106, October 1995
Juan A. DE CASTRO

Yilmaz AKYÜZ \& Andrew CORNFORD

David FELIX

S.M. SHAFAEDDIN

Raju J. SINGH

Thomas ZIESEMER

Sebastian SCHICH

Veena JHA \&

Ana Paola TEIXEIRA

Manuel R. AGOSIN

Yilmaz AKYÜZ \&

Charles GORE

Charles GORE

\section{J. F. OUTREVILLE}

XIE Ping

William W.F. CHOA

Alexandre R. BARROS

Ajit SINGH

Z. KOZUL-WRIGHT

Juan A. DE CASTRO

Roberto FRENKEL

R. KOZUL-WRIGHT
\& Paul RAYMENT

J.C. DE SOUZA BRAGA M.A. MACEDO CINTRA $\&$ Sulamis DAIN

Toni HANIOTIS \& Sebastian SCHICH

Robert ROWTHORN

Giovanni N. DE VITO

John EATWELL
The internalization of external environmental costs and sustainable development

Regimes for international capital movements and some proposals for reform

Industrial development in East Asia: What are the lessons for Latin America?

The impact of trade liberalization on export and GDP growth in least developed countries

Bank credit, small firms and the design of a financial system for Eastern Europe

Economic development and endogenous terms-oftrade determination: Review and reinterpretation of the Presbisch-Singer Thesis

The payment arrangements in the trade of CEECs and LDCs between 1986 and 1994

Are environmentally sound technologies the Emperor's new clothes?

Saving and investment in Latin America

The investment-profits nexus in East Asian industrialization

Development strategy in East Asian newly industrializing economies: The experience of post-war Japan, 1953-1973

Life insurance in developing countries: A crosscountry analysis

Financial services in China

The derivation of trade matrices by commodity groups in current and constant prices

The role of wage stickiness in economic growth

How did East Asia grow so fast? Slow progress towards an analytical consensus

The role of the firm in the innovation process

Trade and labour standards: Using the wrong instruments for the right cause

Macroeconomic sustainability and development prospects: Latin American performance in the 1990s

Walking on two legs: Strengthening democracy and productive entrepreneurship in the transition economies

Financing the public sector in Latin America

Should governments subsidize exports through export credit insurance agencies?

A simulation model of North-South trade

Market distortions and competition: the particular case of Malaysia

Disguised unemployment: The G7 experience 
No. 107, November 1995

No. 108, November 1995

No. 109, December 1995

No. 110, January 1996

No. 111, January 1996

No. 112, March 1996

No. 113, March 1996

No. 114, April 1996

No. 115, April 1996

No. 116, June 1996

No. 117, August 1996

No. 118, September 1996

No. 119, September 1996

No. 120, October 1996

No. 121, October 1996

No. 122, December 1996

No. 123, December 1996

No. 124, March 1997

No. 125, April 1997

No. 126, April 1997

No. 127, May 1997

No. 128, September 1997

No. 129, September 1997

No. 130, March 1998

No. 131, Feb./March 1998
Luisa E. SABATER

David FELIX

Urvashi ZUTSHI

H.A.C. PRASAD

Charles GORE

Djidiack FAYE

Paul BAIROCH \&

Richard KOZUL-WRIGHT

Rameshwar TANDON

E.V.K. FITZGERALD

Jussi LANKOSKI

José RIPOLL

Sunanda SEN

Leena ALANEN

Sinan AL-SHABIBI

J.F. OUTREVILLE

Jörg MAYER

L. RUTTEN \&

L. SANTANA-BOADO

Jörg MAYER

Brigitte BOCOUM

Jussi LANKOSKI

Raju Jan SINGH

E. COSIO-PASCAL

Andrew J. CORNFORD

Matti VAINIO

Robert ROWTHORN \& Richard KOZUL-WRIGHT
Multilateral debt of least developed countries

Financial globalization versus free trade: The case for the Tobin tax

Aspects of the final outcome of the negotiations on financial services of the Uruguay Round

Bilateral terms of trade of selected countries from the South with the North and the South

Methodological nationalism and the misunderstanding of East Asian industrialization

Aide publique au développement et dette extérieure: Quelles mesures opportunes pour le financement du secteur privé en Afrique?

Globalization myths: Some historical reflections on integration, industrialization and growth in the world economy

Japanese financial deregulation since 1984

Intervention versus regulation: The role of the IMF in crisis prevention and management

Controlling agricultural nonpoint source pollution: The case of mineral balances

Domestic insurance markets in developing countries: Is there any life after GATS?

Growth centres in South East Asia in the era of globalization

The impact of environmental cost internalization on sectoral competitiveness: A new conceptual framework

Structural adjustment for the transition to disarmament: An assessment of the role of the market

Reinsurance in developing countries: Market structure and comparative advantage

Implications of new trade and endogenous growth theories for diversification policies of commoditydependent countries

Collateralized commodity financing with special reference to the use of warehouse receipts

Is having a rich natural-resource endowment detrimental to export diversification?

The new mining legislation of Côte d'Ivoire: Some comparative features

Environmental effects of agricultural trade liberalization and domestic agricultural policy reforms

Banks, growth and geography

Debt sustainability and social and human development: The net transfer approach and a comment on the so-called "net" present value calculation for debt relief

Selected features of financial sectors in Asia and their implications for services trade

The effect of unclear property rights on environmental degradation and increase in poverty

Globalization and economic convergence: An assessment 
No. 132, March 1998

No. 133, March 1998

No. 134, April 1998

No. 135, May 1998

No. 136, June 1998

No. 137, June 1998

No. 138, October 1998

No. 139, December 1998

No. 140, February 1999

No. 141, May 1999

No. 142, October 1999
Martin BROWNBRIDGE

Rubens LOPES BRAGA

\section{A.V.GANESAN}

Jene K. KWON

JOMO K.S. \& M. ROCK

Rajah RASIAH

Z. KOZUL-WRIGHT \& Lloyds STANBURY

Mehdi SHAFAEDDIN

M. BRANCHI, G. GABRIELE \& V. SPIEZIA

Lorenza JACHIA \& Ethél TELJEUR

J. François OUTREVILLE
The causes of financial distress in local banks in Africa and implications for prudential policy

Expanding developing countries' exports in a global economy: The need to emulate the strategies used by transnational corporations for international business development

Strategic options available to developing countries with regard to a Multilateral Agreement on Investment

The East Asian model: An exploration of rapid economic growth in the Republic of Korea and Taiwan Province of China

Economic diversification and primary commodity processing in the second-tier South-East Asian newly industrializing countries

The export manufacturing experience of Indonesia, Malaysia and Thailand: Lessons for Africa

Becoming a globally competitive player: The case of the music industry in Jamaica

How did Developed Countries Industrialize? The History of Trade and Industrial Policy: The Cases of Great Britain and the USA

Traditional agricultural exports, external dependency and domestic prices policies: African coffee exports in a comparative perspective

Free trade between South Africa and the European Union - A quantitative analysis

Financial development, human capital and political stability

Copies of UNCTAD Discussion Papers and Reprint Series may be obtained from the Editorial Assistant, Macroeconomic and Development Policies, GDS, UNCTAD, Palais des Nations, CH-1211 Geneva 10, Switzerland (Tel. 41-22-907.5733; Fax 41-22-907.0274; E.mail: nicole.winch@ unctad.org). 